A thematic paper supporting the OECD DAC INCAF project

'Global Factors Influencing the Risk of Conflict and Fragility'

\title{
Out of the Frying Pan into the Fire? Migration from Fragile States to Fragile States
}

Anke Hoeffler

Centre for the Study of African Economies, University of Oxford
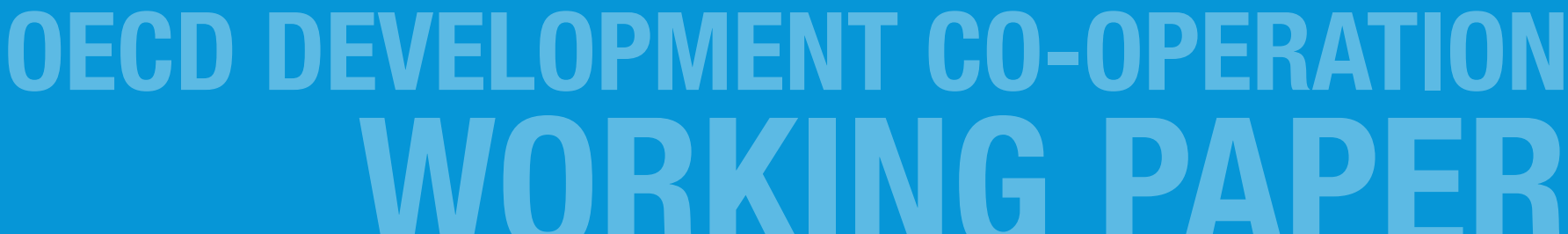

The Development Assistance Committee: Enabling effective development 
This work is published on the responsibility of the Secretary-General of the Organisation for Economic Cooperation and Development (OECD). The opinions expressed and arguments employed herein do not necessarily reflect the official views of the Organisation or of the governments of its member countries.

This document and any map included herein are without prejudice to the status of or sovereignty over any territory, to the delimitation of international frontiers and boundaries and to the name of any territory, city or area.

\section{Note to the reader}

This paper is one of eight thematic papers supporting the OECD DAC INCAF project on Global Factors Influencing the Risk of Conflict and Fragility. Each paper explores a specific global factor. The synthesis report, Think Global, Act Global: Confronting global factors influencing conflict and fragility (OECD, 2012), can be found at:

www.oecd.org/dac/conflictandfragility/globalfactors.htm.

While the thematic papers have been subjected to a robust peer review process, they remain working papers rather than for publication in peer-reviewed journals.

\section{Acknowledgements}

Anke Hoeffler is a research officer at the Centre for the Study of African Economies and a research fellow at St. Antony's College, University of Oxford. The author would like to thank Sylvia Bishop for excellent research assistance. Andrew Zeitlin and Erland Berg provided useful comments. 


\section{Abstract}

Fragile states contributed 18 million migrants and 8 million refugees in 2000. More than 20\% of these migrants and more than half of the refugees settle in other fragile states. Thus, migration is likely to be both a consequence and a possible cause of conflict and fragility. This paper asks why people from fragile states would want to move to another fragile state. Is it simply a question of jumping out of the frying pan into the fire - that migrants from fragile states have no other options than to settle in another fragile state? To investigate this question I analyse a new set of global data on the sources and destinations of migrants. This analysis generates genuinely new research for INCAF, and reveals that economic factors, such as the pull of higher incomes in destination countries, are important. The paper concludes by discussing how migration from fragile states in search of higher incomes and greater wellbeing is an important development strategy that should be supported. The research suggests that a new concept of development may be needed which looks beyond national borders to the countries where the migrants end up. This will require policies to ensure public acceptability in the host countries, however, such as bilateral agreements, temporary status for immigrants and restricting immigration to specific jobs or perhaps regions. 


\section{Table of Contents}

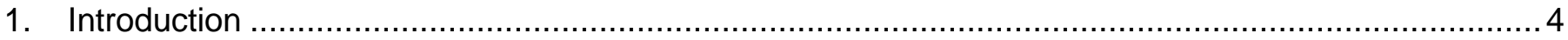

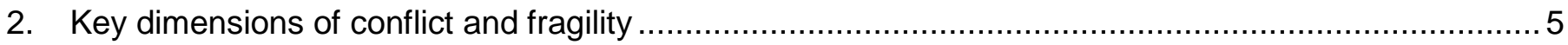

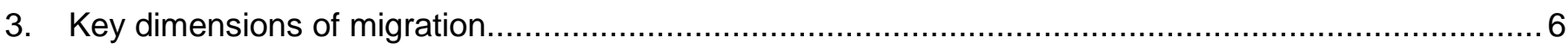

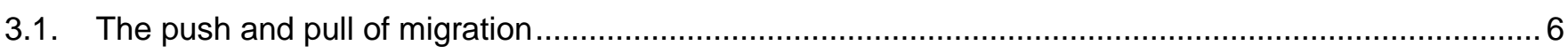

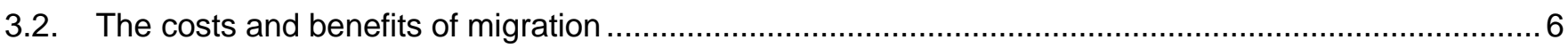

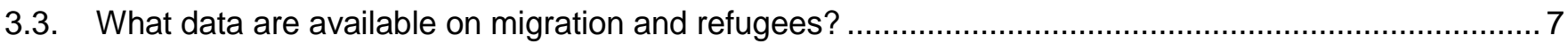

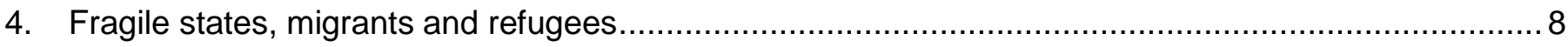

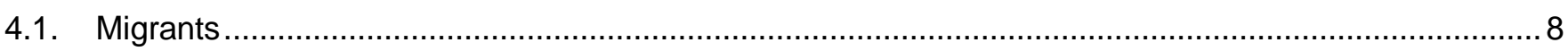

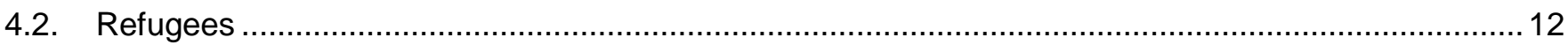

5. Why do migrants from fragile states go to other fragile states?

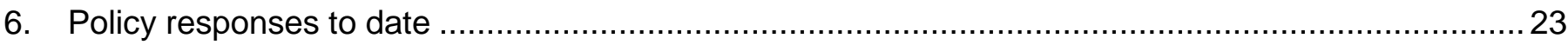

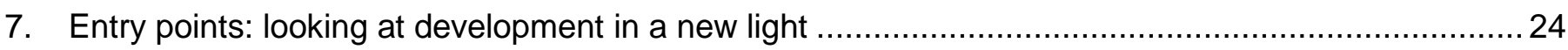

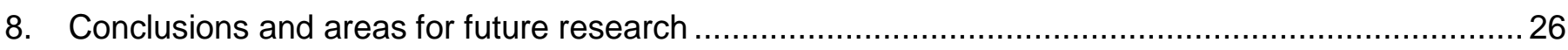

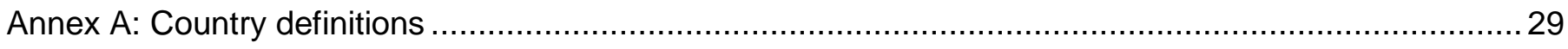

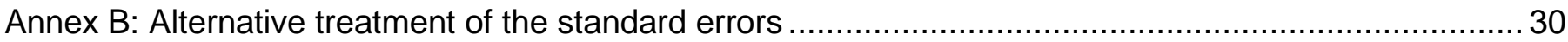

\section{Boxes}

Box 2.1 What do we mean by conflict and fragility? 5

\section{Figures}

Figure 4.1 Where do people live?

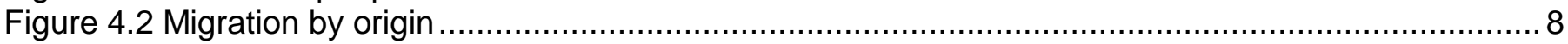

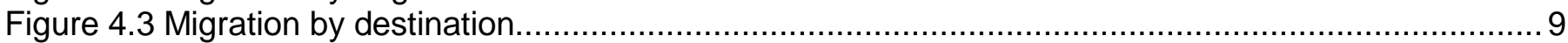

Figure 4.4 Where do migrants from fragile states go?

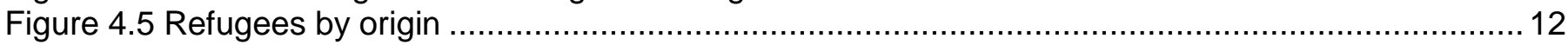

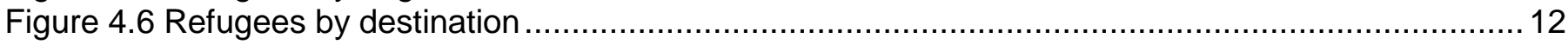

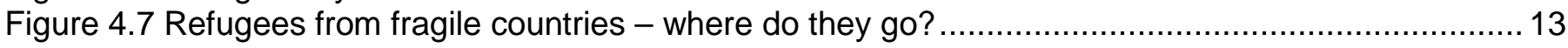

\section{Tables}

Table 4.1. Migration by gender, 2000

Table 4.2 Fragile countries and economies: Where do migrants come from and where do they go to? (2000)

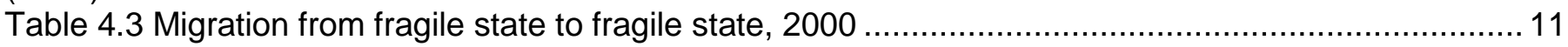

Table 4.4 Where do refugees come from and where do they go to? (2000) …………....................... 13

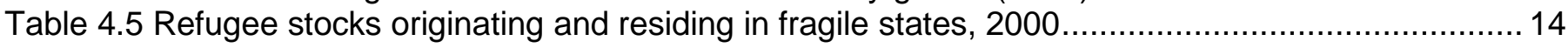

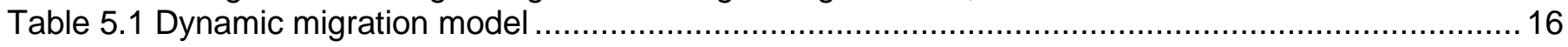




\section{Introduction}

Fragile states (see Box 2.1 for definitions) produced 18 million migrants and an additional 8 million refugees in 2000 . More than $20 \%$ of these migrants and more than half of the refugees settled in other fragile states. Thus, migration is likely to be both a consequence and a possible cause of conflict and fragility.

International data on migrant movements have only recently become available (Özden et al., 2011). These data provide a detailed description of global migration, but they do not provide any statistical analysis of the phenomenon. This paper draws on this global dataset to present some original empirical research on the pattern of migration from fragile states. Using a number of economic, political and geographical indicators it examines why people migrate from one country to another.

Since so many migrants and refugees end up in another fragile state it appears unlikely that their relocation has improved their economic and security status. They seem to have jumped out of the frying pan into the fire, possibly because they had no other choice when they left their home country. This paper explores whether the usual assumptions about migration can also help explain migration from fragile states.

Section 2 outlines some key dimensions of conflict and fragility, while Section 3 does the same for key dimensions of migration, including push and pull factors and costs and benefits, both for migrants and the host and destination countries. In Section $4 \mathrm{I}$ analyse what global data sets on migration and refugees tell us about the people leaving fragile states. In Section 5 I explore this in more detail, by asking why migrants from fragile states move to other fragile states? Using a panel regression model I find that migration from fragile state to fragile state seems to be mainly driven by economic considerations and not by political factors. It appears that migrants do not just jump out of the frying pan into the fire. When they migrate they choose neighbouring countries with a higher income than their own. A brief review of policy responses to date completes the paper, together with an outline of some general areas in which the OECD could increase its understanding of development and migration. 


\section{Key dimensions of conflict and fragility}

The concept of governance is central to the definitions of fragile states in Box 2.1. Both agree that the quality of governance is important for the capacity of citizens to earn a living. In states with poor governance the ability of people to lift themselves out of poverty is severely limited. The prevalence of poverty is high in fragile states: $55 \%$ of their citizens are poor if one takes an income of USD 1.25 a day as the poverty headcount measure. About one-third of the world's poor live in fragile states even though these states only account for $15 \%$ of the global population. ${ }^{i}$

\section{Box 2.1 What do we mean by conflict and fragility?}

As a starting point it is useful to define "conflict and fragility". For the purposes of this paper I want to use a definition of conflict and fragility which enables me to link the theoretical definition to empirical measures.

\section{Fragility}

The OECD defines a fragile state broadly as follows: "A fragile state has weak capacity to carry out basic functions of governing a population and its territory, and lacks the ability to develop mutually constructive and reinforcing relations with society." (OECD, 2011).

Another definition explains how fragility characterises states that are unable to provide two basic functions: security and economic opportunity (Chauvet et al., 2010 \& 2011): (1) The most basic role of the state is to provide physical security to its citizens by maintaining a monopoly of organised violence within the society. Where the government fails to do this and rival organisations of violence emerge, the state descends into civil war. (2) Governments play some role as regulators of private economic activity, and as suppliers of public goods such as transport infrastructure, health and education.

The OECD (2010) has compiled a list of 43 fragile states (see Annex A). This empirical research focuses on that list. Although it is unclear which cut-off points were used to categorise these countries as "fragile", it is a useful list for empirical purposes.

\section{Conflict}

To my knowledge there is no OECD definition of conflict. In this paper I define conflict following Gleditsch et al. (2002). In their global data set they make a distinction between "major" and "minor" armed conflict. Major armed conflicts or wars cause at least 1000 battle-related deaths per year (military and civilian deaths). Another part of the definition is that there is organised effective violent opposition to the government: this distinguishes this type of violence from genocides, pogroms and communal violence. In this paper I consider conflicts that are internal to a country, i.e. civil wars. 


\section{Key dimensions of migration ${ }^{\mathrm{ii}}$}

\subsection{The push and pull of migration}

Migration is a typical human activity; ever since developing into modern humans we have been on the move. Today about $3 \%$ of the world's population are migrants; this ratio has remained relatively stable over the past 50 years (Özden et al., 2011).

People leave their country of origin for different reasons. Some are forced to leave due to war, environmental degradation and environmental disasters (floods, droughts). Refugees include individuals recognised under the 1951 UN Convention on to the Status of Refugees and are defined as person who, "owing to a well-founded fear of being persecuted for reasons of race, religion, nationality, membership of a particular social group, or political opinion, is outside the country of his nationality, and is unable to or, owing to such fear, is unwilling to avail himself of the protection of that country" (cited in UNHCR, 2010). Since most countries have signed the 1951 convention and additional protocols there is an accepted international definition of refugees, which makes it easy to count them.

Others (voluntary migrants) choose to migrate to another country to improve their welfare or to pursue better economic opportunities. In reality there is a continuum of motivations, from voluntary to forced, ${ }^{\text {iii }}$ and the theoretical distinction between voluntary and forced migration is fuzzy.

Many factors, such as family ties, security, values, opportunities and international regulation influence the decision to migrate. For most of those people leaving fragile states it is most likely that the decision to move is not voluntary. Therefore in this paper I distinguish between migrants and refugees so as to examine the factors behind both flows.

\subsection{The costs and benefits of migration}

Migration has both benefits and costs for both origin and destination countries. Households in origin countries benefit from remittances, which can considerably increase their incomes. One obvious consequence of migrating to a country with higher wages is that the migrant's wellbeing is increased. Families and communities in the countries of origin also benefit from receiving remittances. These private transfers dwarf development aid: In 2009 about USD 236 billion in remittances were transferred to poor and middle income countries, while official development aid to these countries was about USD 90 billion. Remittances have been associated with declines in the poverty headcount ratio in several low-income countries - by 11 percentage points in Uganda, 6 in Bangladesh, and 5 in Ghana (World Bank, 2006). ${ }^{\text {iv }}$ Thus, migration can provide a way out of poverty.

The costs of emigration are currently not well understood. One concern is that if a relatively large proportion of the skilled workers emigrate from poorer countries this may cause a skills shortage, commonly referred to as "brain drain" However, Docquier and Rapoport (2009) show that countries can still benefit from educating a large pool of experts even if a high number emigrate. This gain occurs by educating more experts than they can "export" and through return migrants. For India they suggest a clear "brain gain" from information technology migration, while it is unclear whether the "medical migration" from Africa constitutes a gain or drain. Another possible 
impact of migration is the effect of emigration on home country institutions. There are very few studies of these effects. One large unpublished study suggests that emigration can increase the fragility of the origin country, perhaps by undermining their institutions (Docquier et al., 2009). However, one micro study of Cape Verde shows that emigration raises the demand for political accountability (Batista and Vicente, 2012).

Destination countries face a number of economic and social costs. Potential costs include: unemployment, lower wages, threats to national security, increasing cultural differences and challenges to the social peace. However, an economic analysis of migration suggests that rich countries overall benefit from immigration, including an increase and diversification of the work force. Incomes of the indigenous population increase by $0.4 \%$ on average as a result (World Bank, 2006).

However, while research has been done on the economic impact of migration to OECD countries, little work has been done on the impact of migration on fragile states.

\subsection{What data are available on migration and refugees?}

It is only recently that global migration data have become available. Today there are useful global data sets on both migration and refugees: Özden et al. (2011) provide data on migrants which excludes refugees, and the United Nations has data on refugees (UNHCR, 2011).

Özden et al.'s data have made it possible to study the migration phenomenon in a statistical model. They define migrants as people living in one country but having been born in another country. The data set covers all countries and provides the number of migrants originating from country i now living in country $\mathrm{j}$. The data are provided in country pairs (or dyads). The data set provides migrant population numbers (referred to as "stock") for 1960, 1970, 1980, 1990 and 2000 in 175 countries. Information on the origin and destination of migrants is available for all of the 43 fragile countries listed in Annex A.

The UNHCR provides refugee figures by origin and destination (UNHCR, 2012). It mainly relies on records provided by the host country. Data can be obtained from the UNHCR website ${ }^{v}$ by country pair; in order to make it comparable to my migration analysis I use data from 1970, 1980, 1990 and 2000. ${ }^{\mathrm{vi}}$ In addition the UNHCR provides information on "other persons of concern"; this category includes internally displaced persons (IDPs). However, in my analysis I only consider refugees, i.e. people who have settled outside their home country.

\section{NOTES}

\footnotetext{
'Author's own calculations using the World Development Indicators (ESDS International, 2011).

ii In this analysis I concentrate on cross-border migration and do not consider moves within countries.

iii See Richmond (1994) and van Hear (1998) for a categorisation of forced and voluntary migration.

iv The flow and use of remittances is well studied and the World Bank (2006) report provides a long list of references.

${ }^{v}$ See www.unhcr.org/statistics/STATISTICS/45c06c662.htm/\#refugees, accessed 25 January 2012.

${ }^{v i}$ Data for the early 1960 s are too sparse to be used in this panel data analysis.
} 


\section{Fragile states, migrants and refugees}

\subsection{Migrants}

In 2000 about $13 \%$ of the world's population lived in fragile states (Figure 4.1), but only about $11 \%$ of the world's migrants originated from fragile states (Figure 4.2). ${ }^{i}$ Thus, even though there are strong push factors in fragile states that make emigration desirable, the number of migrants from these countries is disproportionately low. Migration requires investment - very low incomes make such investment impossible (Collier and Hoeffler, 2011). Populations may become trapped in poverty and are unable to migrate (Foresight, 2011).

Figure 4.1 Where do people live?

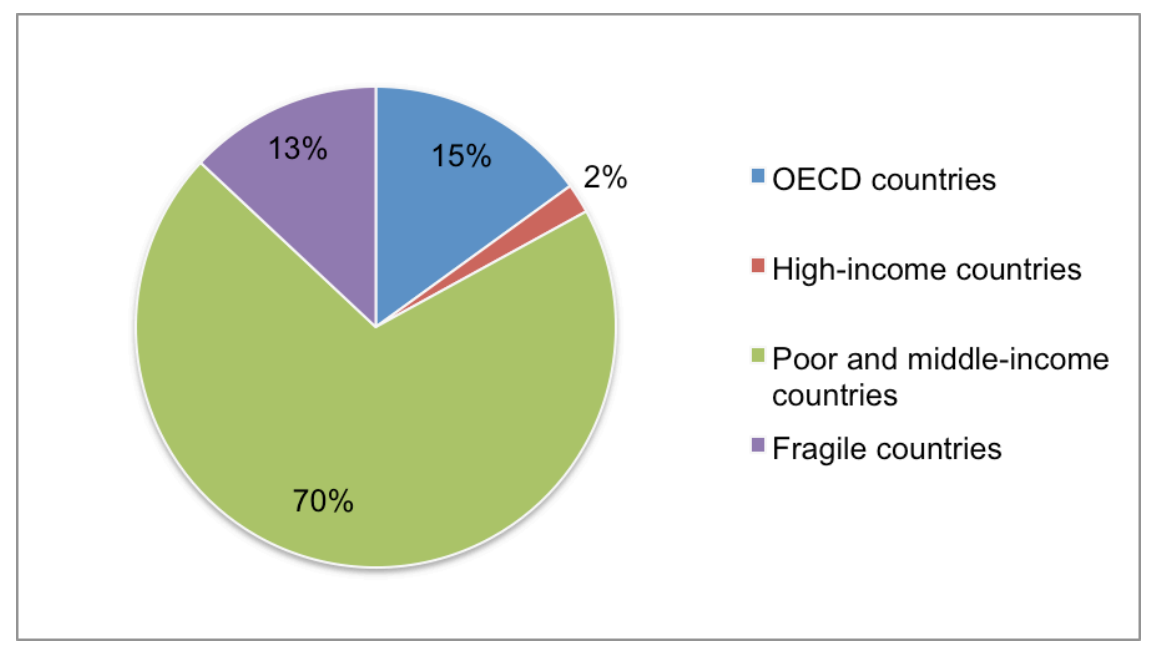

Note: World population in 2000; see Annex A for definitions of the different country categories Source: based on ESDS International (2011), World Development Indicators, ESDS International, University of Manchester, Manchester.

Figure 4.2 Migration by origin

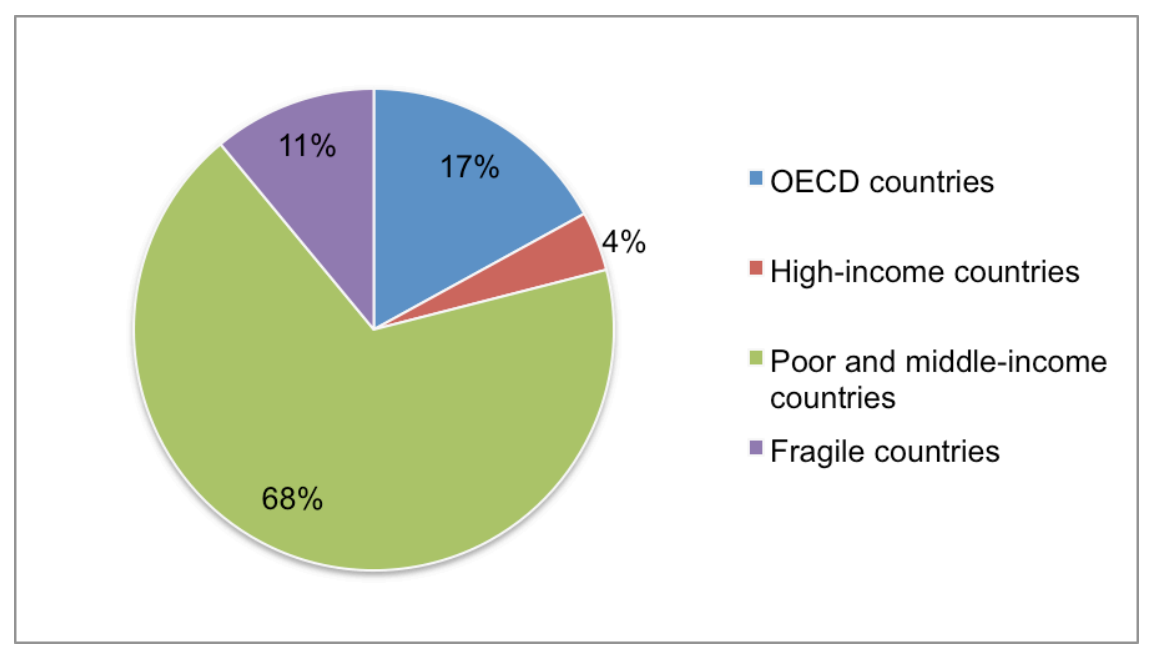

Note: Migrants in 2000; see Annex A for definitions of the different country categories

Source: based on data from Özden, Ç., Parsons, C. R., Schiff, M. and T.L. Walmsley (2011), "Where on Earth is Everybody? The Evolution of Global Bilateral Migration 1960-2000", World Bank Economic Review 25(1): 12-56. 
When people are able to migrate, where do they go? Figure 4.3 shows that the high income OECD countries are the most popular destination: about half of the world's migrants live there. However, when we consider migrants from fragile states only we see a different pattern: only about $23 \%$ live in a high income OECD country and almost $20 \%$ of migrants from fragile states have settled in another fragile state (Figure 4.4). It seems they are jumping out of the frying pan into the fire - leaving one bad place for another. Would a statistical model be able to explain this phenomenon? Or perhaps due to their very limited options, migrants are forced to settle in another fragile country, in which case a statistical approach would not be helpful.

Figure 4.3 Migration by destination

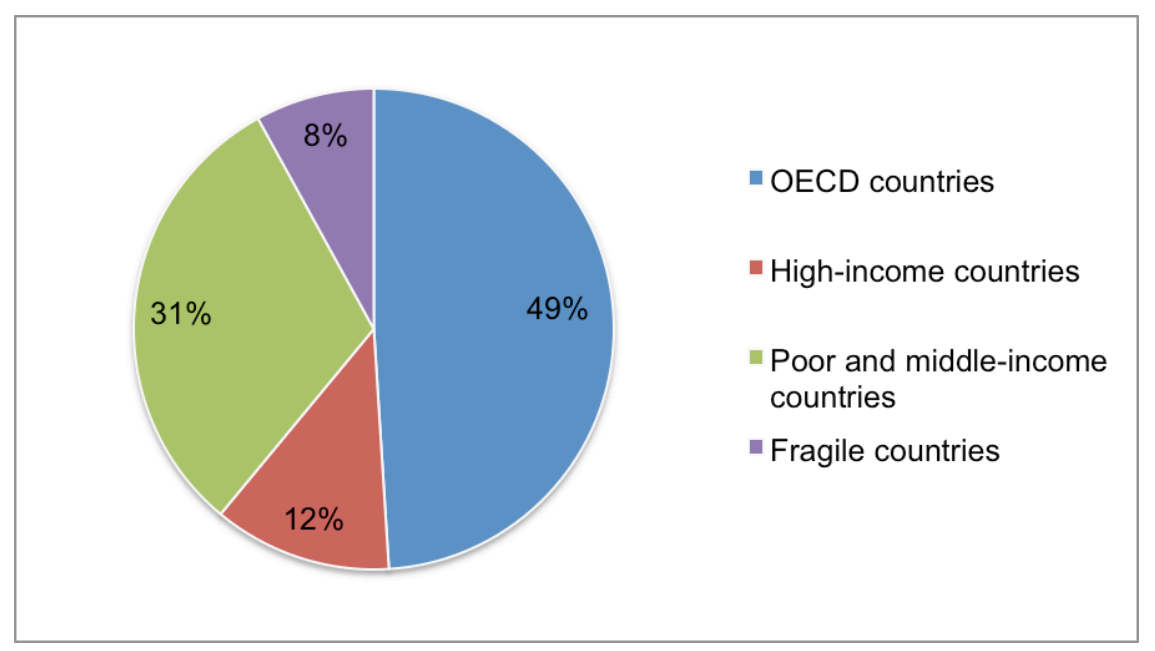

Note: Migrants in 2000; see Annex A for definitions of the different country categories

Source: based on data from Özden, Ç., Parsons, C. R., Schiff, M. and T.L. Walmsley (2011), "Where on Earth is Everybody? The Evolution of Global Bilateral Migration 1960-2000", World Bank Economic Review 25(1): 12-56.

Figure 4.4 Where do migrants from fragile states go?

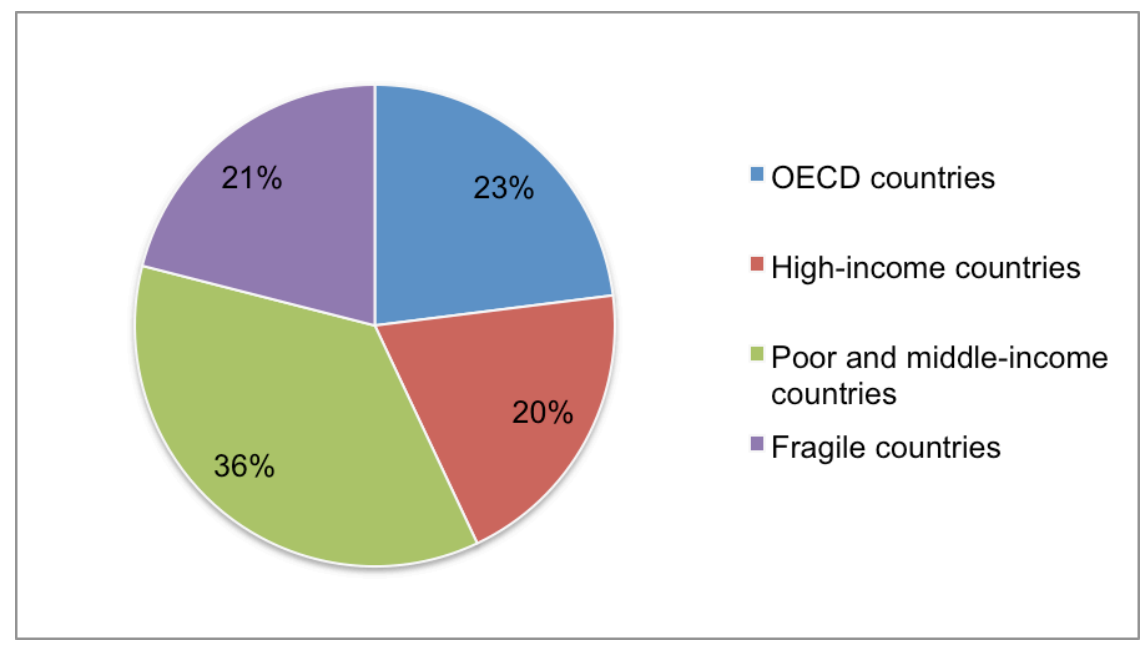

Note: Migrants from fragile states in 2000; see Annex A for definitions of the different country categories

Source: based on data from Özden, Ç., Parsons, C. R., Schiff, M. and T.L. Walmsley (2011), "Where on Earth is Everybody? The Evolution of Global Bilateral Migration 1960-2000", World Bank Economic Review 25(1): 12-56.

Despite being comprehensive in its country coverage, the migration database provides only limited information on migrants. We only know how many migrants there are at a particular point in time. We do not know when they moved or for how long they have been in a particular country, 
and we have almost no personal information on them. The only additional information is the sex of the migrant (Table 4.1). As the table suggests, for most countries the gender split is almost half and half. However, for the fragile countries the gender composition is different: about $55 \%$ of migrants from fragile states are men.

Table 4.1. Migration by gender, 2000

\begin{tabular}{|l|c|c|}
\hline \multicolumn{1}{|c|}{ Origin } & $\begin{array}{c}\text { Female } \\
\%\end{array}$ & \multicolumn{1}{c|}{ Male } \\
\hline OECD countries & 51.7 & 48.3 \\
\hline High-income countries & 50.4 & 49.6 \\
\hline Middle-income \& poor countries & 49.6 & 49.9 \\
\hline Fragile states & 45.0 & 55.2 \\
\hline
\end{tabular}

Note: Migration by origin in 2000; see Annex A for definitions of the different country categories.

Source: Özden, Ç., Parsons, C. R., Schiff, M. and T.L. Walmsley (2011), "Where on Earth is Everybody? The Evolution of Global Bilateral Migration 1960-2000", World Bank Economic Review 25(1): 12-56.

First let's take a more detailed look at where migrants come from and where they go to. Table 4.2 lists the top origin and destination countries. Almost $40 \%$ of the migrants from fragile states come from four South Asian and Middle Eastern countries/economies: Pakistan, Afghanistan, Iraq, and West Bank and Gaza. About 40\% of all migrants settle in six countries: India, Saudi Arabia, USA, Iran, the UAE and the UK. It appears that many migrants from fragile states either move to a neighbouring country or else to a distant country with a very high income.

Table 4.2 Origins and destinations of migrants from fragile countries and economies, 2000

\begin{tabular}{|c|c|c|c|c|c|}
\hline $\begin{array}{c}\text { Fragile country } \\
\text { or economy of } \\
\text { origin }\end{array}$ & Total migrants & $\begin{array}{c}\text { Female } \\
\text { (\% of total) }\end{array}$ & $\begin{array}{l}\text { Country of } \\
\text { destination }\end{array}$ & $\begin{array}{c}\text { Total } \\
\text { migrants }\end{array}$ & $\frac{\text { Female }}{(\% \text { of total) }}$ \\
\hline Pakistan & 3804717 & 39.0 & India & 2083511 & 49.9 \\
\hline Afghanistan & 1179574 & 40.1 & Saudi Arabia & 1434023 & 32.2 \\
\hline Iraq & 1029812 & 42.0 & USA & 1409163 & 47.5 \\
\hline $\begin{array}{l}\text { West Bank \& } \\
\text { Gaza }\end{array}$ & 965843 & 45.9 & Iran & 941848 & 40.8 \\
\hline Nepal & 768574 & 50.9 & UAE & 836052 & 26.2 \\
\hline Haiti & 768141 & 47.3 & UK & 771327 & 49.8 \\
\hline Nigeria & 656653 & 44.3 & Syria & 490032 & 49.0 \\
\hline DRC & 627851 & 52.5 & Kenya & 473271 & 50.1 \\
\hline Yemen & 613354 & 28.8 & Burkina Faso & 453206 & 49.6 \\
\hline Sudan & 593840 & 39.8 & Kuwait & 450901 & 37.3 \\
\hline Tajikistan & 549556 & 49.8 & South Korea & 436336 & 52.7 \\
\hline Côte d'Ivoire & 549023 & 48.7 & Ethiopia & 413118 & 47.4 \\
\hline North Korea & 544153 & 54.0 & Russian Fed. & 382585 & 50.6 \\
\hline Uganda & 533602 & 50.6 & Uganda & 363055 & 50.1 \\
\hline Guinea & 424062 & 43.5 & Rwanda & 343381 & 54.2 \\
\hline
\end{tabular}




\begin{tabular}{|l|l|l|l|l|l|}
\hline Somalia & 376066 & 50.6 & Côte d'Iv. & 326082 & 45.8 \\
\hline Angola & 373485 & 49.0 & Sudan & 320457 & 48.5 \\
\hline Kenya & 371243 & 50.3 & Canada & 312407 & 46.2 \\
\hline Zimbabwe & 367629 & 49.4 & Dom.Rep. & 229016 & 35.9 \\
\hline Eritrea & 359170 & 45.6 & Guinea & 222229 & 53.6 \\
\hline
\end{tabular}

Note: top 20 countries/economies of origin and of destination, only migrants from fragile countries/economies, 2000 Source: Özden, Ç., Parsons, C. R., Schiff, M. and T.L. Walmsley (2011), "Where on Earth is Everybody? The Evolution of Global Bilateral Migration 1960-2000", World Bank Economic Review 25(1): 12-56.

Table 4.3 provides more detail on migration from fragile state to fragile state. Other destinations are excluded. A number of fragile states have a high number of emigrants as well as immigrants. The Democratic Republic of Congo (DRC), Uganda, Guinea, Sudan and Rwanda are among the top 10 emigration as well as immigration countries. This high degree of regional mobility seems to be a particular characteristic of fragile African countries. The last column of Table 4.3 lists the number of migrants by country pair: for example, about 350000 Ugandans live in Kenya; 290000 Congolese live in Rwanda and 255000 Eritreans live in Ethiopia.

Table 4.3 Migration from fragile state to fragile state, 2000

\begin{tabular}{|c|c|c|c|c|c|c|}
\hline $\begin{array}{l}\text { Top origin } \\
\text { countries }\end{array}$ & total & $\begin{array}{l}\text { Top destination } \\
\text { countries }\end{array}$ & total & $\begin{array}{l}\text { Top origin } \\
\text { dyads }\end{array}$ & lestination & total \\
\hline DRC & 495918 & Kenya & 473271 & Uganda & Kenya & 351083 \\
\hline Uganda & 436193 & Ethiopia & 413118 & DRC & Rwanda & 288278 \\
\hline Guinea & 278448 & Uganda & 363055 & Eritrea & Ethiopia & 255018 \\
\hline Eritrea & 276956 & Rwanda & 343381 & Sudan & Uganda & 149360 \\
\hline Sudan & 240220 & Côte d'Ivoire & 326082 & Guinea & Côte d'Ivoire & 129807 \\
\hline Nigeria & 232660 & Sudan & 320457 & Liberia & Guinea & 117820 \\
\hline Rwanda & 205583 & Guinea & 222229 & Somalia & Ethiopia & 101938 \\
\hline Liberia & 197781 & Nigeria & 220134 & Sierra Leo. & Guinea & 97669 \\
\hline Somalia & 189272 & Cameroon & 165234 & DRC & Uganda & 86624 \\
\hline Niger & 139572 & DRC & 117659 & Togo & Nigeria & 76914 \\
\hline Togo & 134969 & Sierra Leone & 84908 & Nigeria & Cameroon & 72187 \\
\hline Burundi & 130967 & Djibouti & 83177 & Rwanda & Uganda & 65400 \\
\hline Chad & 122489 & Chad & 78260 & Chad & Cameroon & 65397 \\
\hline Sierra Leo. & 114086 & Yemen & 63921 & Rwanda & Sudan & 60380 \\
\hline Kenya & 98537 & Pakistan & 57532 & Guinea & Sierra Leone & 58908 \\
\hline Iraq & 78354 & Gambia & 54629 & Niger & Nigeria & 58115 \\
\hline Cameroon & 70618 & Liberia & 54284 & Niger & Côte d'Ivoire & 57705 \\
\hline Ethiopia & 51927 & Niger & 47007 & Iraq & Yemen & 53675 \\
\hline Pakistan & 43733 & Burundi & 44728 & DRC & Sudan & 53612 \\
\hline Nepal & 41992 & Togo & 39917 & Burundi & Sudan & 51746 \\
\hline
\end{tabular}

Source: Özden, Ç., Parsons, C. R., Schiff, M. and T.L. Walmsley (2011), "Where on Earth is Everybody? The Evolution of Global Bilateral Migration 1960-2000", World Bank Economic Review 25(1): 12-56. 


\subsection{Refugees}

I now turn to the refugee data. In order to compare the refugee data with the migration data I use 2000 as the reference year, even though refugee data are available for 2010. As Figure 4.5 shows, $77 \%$ of all refugees come from countries affected by conflict and fragility. Forty-four per cent of all refugees, irrespective of country of origin, settle in fragile states, $44 \%$ in poor and middle income countries and $12 \%$ in the OECD. A negligible number (less than $0.5 \%$ ) settles in other high income countries (Figure 4.6). When only refugees from fragile countries are considered, the countries of asylum are slightly different. Figure 4.7 shows that only $6 \%$ obtain refuge in the OECD, $40 \%$ in poor and middle income countries and the majority (54\%) finds asylum in another fragile state.

Figure 4.5 Refugees by origin

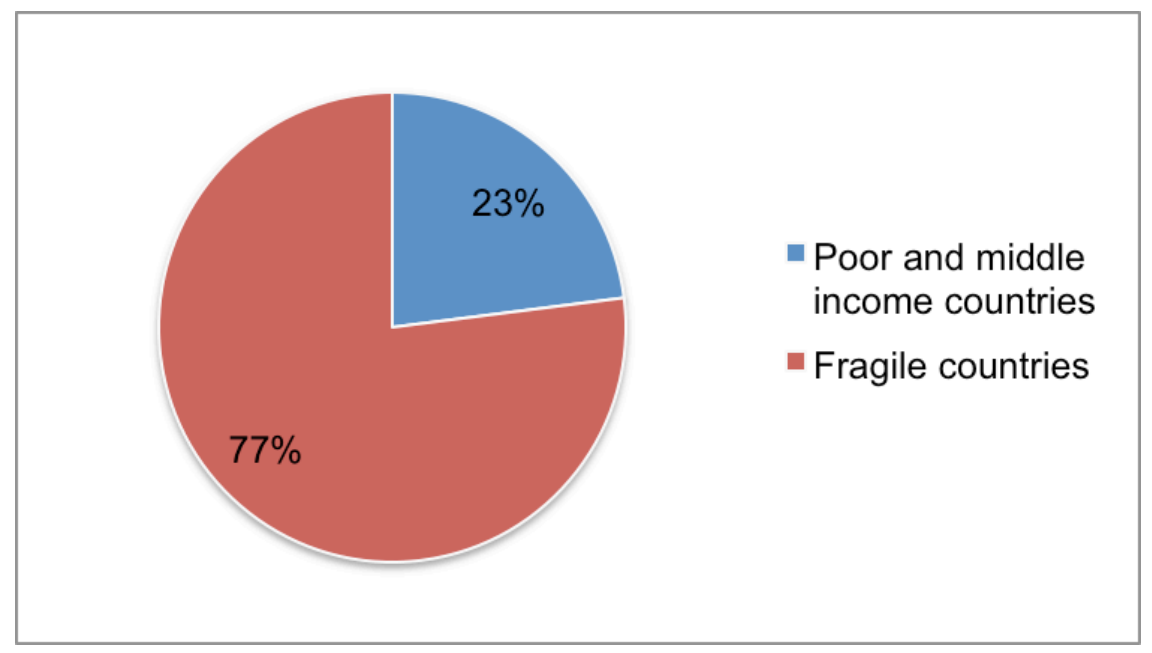

Note: Refugees in 2000

Source: based on data from UNHCR (United Nations High Commissioner for Refugees) (2012), UNHCR Statistical Online Population Database, UNHCR, New York, available at www.unhcr.org/pages/4a013eb06.html ${ }_{2}$ accessed 25 October 2012.

Figure 4.6 Refugees by destination

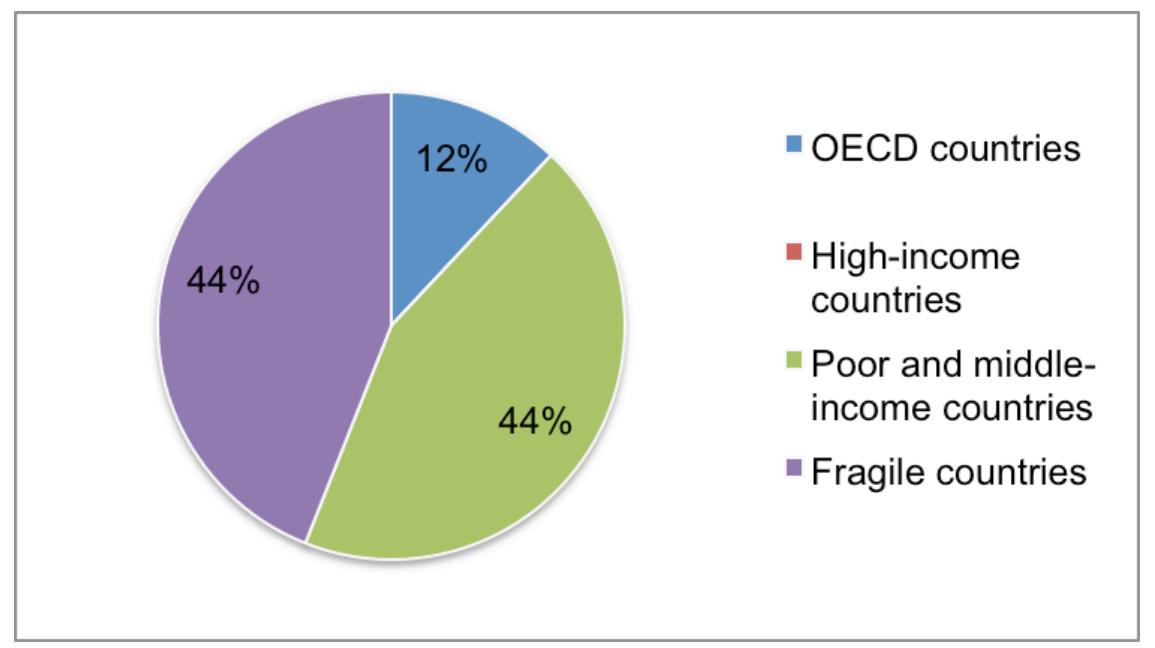

Note: Refugees in 2000

Source: based on UNHCR (United Nations High Commissioner for Refugees) (2012), UNHCR Statistical Online Population Database, UNHCR, New York, www.unhcr.org/pages/4a013eb06.html, accessed 25 October 2012. 
Figure 4.7 Refugees from fragile countries - where do they go?

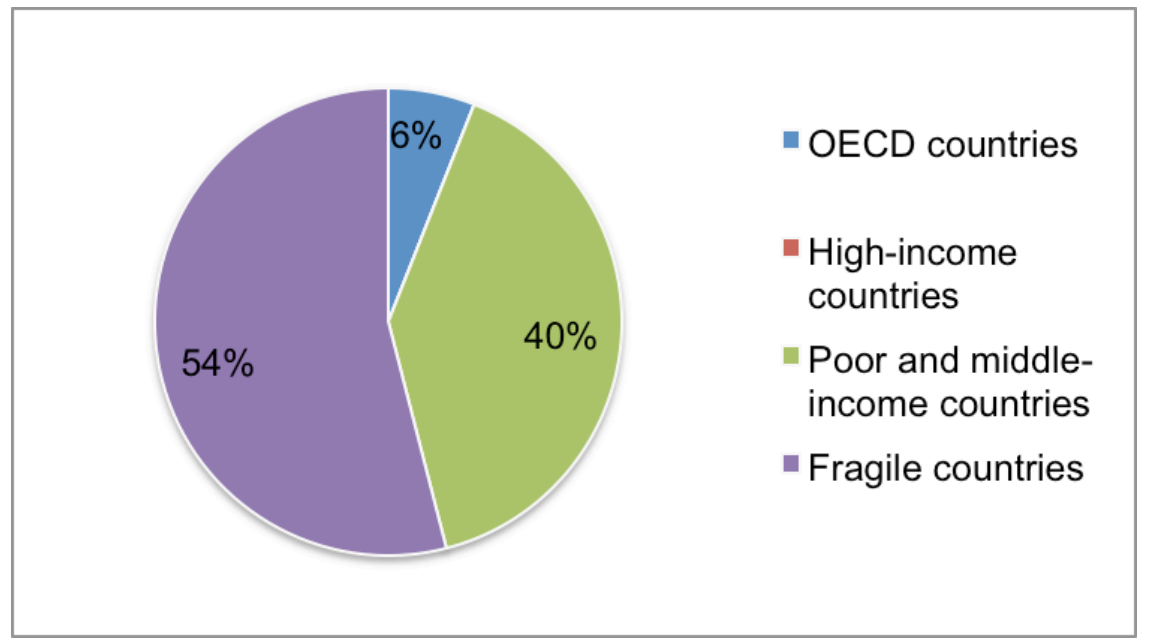

Note: Refugees from fragile countries in 2000

Source: based on UNHCR (United Nations High Commissioner for Refugees) (2012), UNHCR Statistical Online Population Database, UNHCR, New York, www.unhcr.org/pages/4a013eb06.html, accessed 25 October 2012.

Tables 4.4 and 4.5 take a closer look at where refugees come from and where they go to. In 2000 about one-third of all refugees (3.6 million) fled Afghanistan. Most of them (about 2 million) found refuge in neighbouring Pakistan. Other civil war countries also generated a lot of refugees: Angola, Azerbeijan, Bosnia and Herzogovina and Burundi are next on the list. The most popular destinations for these people were Pakistan, Iran, Tanzania and Guinea. Only three OECD countries - USA, Sweden and the Netherlands - are among the top 20 destinations. Table 4.5 lists the country pairs with the highest refugee numbers. Only refugees from and to fragile states are considered. The 2 million Afghan refugees in Pakistan head the list, followed by almost exclusively African refugees. All of these African refugees obtained asylum in another African state. The only non-African country pair are the 90000 Palestinian refugees in Iraq.

Table 4.4 Where do refugees come from and where do they go to? (2000)

\begin{tabular}{|l|l|l|l|}
\hline $\begin{array}{l}\text { 20 top countries (by } \\
\text { origin) }\end{array}$ & $\begin{array}{l}\text { Refugees fleeing in } \\
2000\end{array}$ & $\begin{array}{l}\text { 20 top countries by } \\
\text { destination }\end{array}$ & $\begin{array}{l}\text { Refugees arriving } \\
\text { in } 2000\end{array}$ \\
\hline Afghanistan & 3600000 & Pakistan & 2000000 \\
\hline Angola & 433760 & Iran & 1900000 \\
\hline Azerbaijan & 284277 & Tanzania & 679223 \\
\hline Bosnia \& Herzegovina & 474981 & Serbia & 484391 \\
\hline Burundi & 568084 & Guinea & 427206 \\
\hline China & 131943 & USA & 417131 \\
\hline DRC & 371713 & Sudan & 414928 \\
\hline Croatia & 335199 & DRC & 332490 \\
\hline Eritrea & 376851 & China & 294110 \\
\hline Iraq & 526179 & Armenia & 280591 \\
\hline Liberia & 266930 & Zambia & 250509 \\
\hline
\end{tabular}




\begin{tabular}{|l|l|l|l|}
\hline Burma & 137128 & Uganda & 236622 \\
\hline Rwanda & 119056 & Kenya & 205998 \\
\hline Serbia & 146748 & Ethiopia & 197959 \\
\hline Sierra Leone & 402807 & India & 170941 \\
\hline Somalia & 475655 & Sweden & 149625 \\
\hline Sri Lanka & 124160 & Netherlands & 140859 \\
\hline Sudan & 494363 & Nepal & 129237 \\
\hline East Timor & 122202 & Iraq & 127687 \\
\hline Vietnam & 370758 & Congo & 123190 \\
\hline
\end{tabular}

Source: UNHCR (United Nations High Commissioner for Refugees) (2012), UNHCR Statistical Online Population Database, UNHCR, New York, www.unhcr.org/pages/4a013eb06.html, accessed 25 October 2012.

Table 4.5 Refugee stocks originating and residing in fragile states, 2000

\begin{tabular}{|l|l|l|}
\hline Country I economy of origin & Country of destination & No. of refugees in country of destination \\
\hline Afghanistan & Pakistan & 2000000 \\
\hline Eritrea & Sudan & 367735 \\
\hline Sierra Leone & Guinea & 310024 \\
\hline Sudan & Uganda & 212156 \\
\hline Angola & DRC & 175420 \\
\hline Somalia & Kenya & 137376 \\
\hline Somalia & Ethiopia & 121096 \\
\hline Liberia & Côte d'Ivoire & 117749 \\
\hline Liberia & Guinea & 117069 \\
\hline DRC & Congo & 97600 \\
\hline West Bank \& Gaza & Iraq & 90000 \\
\hline Sudan & DRC & 72910 \\
\hline Sudan & Ethiopia & 71732 \\
\hline Sierra Leone & Liberia & 69266 \\
\hline Somalia & Yemen & 56524 \\
\hline Sudan & Kenya & 55585 \\
\hline Rwanda & DRC & 46280 \\
\hline Chad & Cameroon & 42325 \\
\hline Sudan & Central African Republic & 36151 \\
\hline Ethiopia & Sudan & 34132 \\
\hline Source: & & $12012)$ \\
\hline
\end{tabular}

Source: UNHCR (United Nations High Commissioner for Refugees) (2012), UNHCR Statistical Online Population Database, UNHCR, London, www.unhcr.org/pages/4a013eb06.html, accessed 25 October 2012. 
To summarise, fragile countries have a relatively low proportion of emigrants but a disproportionately high number of refugees. Migrants and refugees settle mostly in neighbouring countries, many of which are fragile themselves. A relatively small proportion of migrants from fragile states settle in the OECD (23\%) and even fewer refugees find asylum in an OECD country $(6 \%)$. In the next section we turn to our statistical model to analyse the patterns of (forced) migration in more detail.

\section{NOTES}

\footnotetext{
i Since the most recent available data are for 2000 the data description focuses on this year. Undoubtedly, one conceptual criticism is that not all of the countries that are currently classified as fragile were fragile in 2000 . Other countries would undoubtedly have been classified as fragile in 2000 but have since then stabilised (for example the Balkan countries). However, since the censuses around the year 2011 have not been processed yet, there are no more recent data available.
} 


\section{Why do migrants from fragile states go to other fragile states?}

The methods used in this analysis follow the approach I took in a previous study of global migration, although based on more limited data coverage than the present study (Collier and Hoeffler, 2011). Global data were only available for 2000 and data for OECD countries for 1990 and 2000.i

Table 5.1 examines international migration and refugee flows using dynamic panel regression. The analysis consists of a number of steps. Each column documents the results from each step. In order to relate the current research to my previous analysis (Collier and Hoeffler, 2011) I start by examining the migration from all poor and middle income countries to the rest of the world (column 1). I then develop a similar model for migration from fragile states to the rest of the world, before restricting the analysis to migration from fragile states to fragile states (column 4). Finally, I consider refugee flows and investigate whether the previously developed migration models can help explain forced migration.

There is some concern whether stepwise restriction of the sample is useful. Since the sample sizes are different no direct comparisons of coefficient estimates can be made across the different models. However, since refugees predominately originate from fragile states and settle in fragile states it is useful to restrict the migration sample in order to make it comparable to the refugee analysis. Since I am concerned about the difficulty of comparing across different samples I ran some models with dummy variables.

Table 5.1 Dynamic migration model

\begin{tabular}{|c|c|c|c|c|c|c|}
\hline & (1) & $(2)$ & $(3)$ & $(4)$ & $(5)$ & $(6)$ \\
\hline & $\begin{array}{c}\text { Poor \& } \\
\text { middle } \\
\text { income to } \\
\text { world }\end{array}$ & $\begin{array}{c}\text { Fragile to } \\
\text { world }\end{array}$ & $\begin{array}{l}\text { Fragile to } \\
\text { world \& } \\
\text { dummy }\end{array}$ & $\begin{array}{l}\text { Fragile to } \\
\text { fragile }\end{array}$ & $\begin{array}{l}\text { Refugees- } \\
\text { fragile to } \\
\text { fragile }\end{array}$ & $\begin{array}{l}\text { Refugee } \\
\text { model } \\
\text { fragile to } \\
\text { fragile }\end{array}$ \\
\hline \multirow[t]{2}{*}{ In Diaspora } & 0.844 & 0.851 & 0.849 & 0.850 & & \\
\hline & $(0.022)^{\star \star \star}$ & $(0.029)^{\star \star \star}$ & $(0.029)^{\star \star \star}$ & $(0.027)^{\star \star \star}$ & & \\
\hline \multirow[t]{2}{*}{ Colony } & -1.381 & 0.269 & 0.253 & & & \\
\hline & $(0.837)$ & $(0.231)$ & $(0.232)$ & & & \\
\hline \multirow[t]{2}{*}{ neighbour } & 4.437 & -0.285 & -0.296 & -0.908 & 13.885 & -0.878 \\
\hline & $(1.476)^{\star \star \star}$ & $(0.685)$ & $(0.690)$ & $(5.943)$ & $(7.119)^{\star}$ & (6.923) \\
\hline \multirow[t]{2}{*}{ Km distance } & -0.968 & -0.850 & -0.849 & -0.111 & -0.132 & -0.506 \\
\hline & $(0.121)^{\star \star \star}$ & $(0.167)^{\star \star \star}$ & $(0.166)^{\star \star \star}$ & $(0.025)^{\star \star \star}$ & $(0.024)^{\star \star \star}$ & $(0.585)$ \\
\hline \multirow[t]{2}{*}{ Inpopulationo_1 } & 0.284 & 0.255 & 0.256 & 0.109 & -0.014 & 0.072 \\
\hline & $(0.030)^{\star \star \star}$ & $(0.040)^{\star \star \star}$ & $(0.039)^{\star \star \star}$ & $(0.047)^{\star \star}$ & $(0.039)$ & $(0.044)$ \\
\hline \multirow[t]{2}{*}{ Inpopulationd_1 } & 0.391 & 0.372 & 0.384 & 0.161 & 0.182 & 0.304 \\
\hline & $(0.056)^{\star \star \star}$ & $(0.065)^{\star \star \star}$ & $(0.065)^{\star \star \star}$ & $(0.088)^{\star}$ & $(0.087)^{\star \star}$ & $(0.093)^{\star \star \star}$ \\
\hline \multirow[t]{2}{*}{ InGDPo_1 } & -0.229 & -0.052 & -0.051 & 0.198 & -0.062 & -0.492 \\
\hline & $(0.076)^{\star \star \star}$ & $(0.086)$ & $(0.086)$ & $(0.077)^{\star \star}$ & $(0.075)$ & $(0.151)^{\star \star \star}$ \\
\hline \multirow[t]{2}{*}{ InGDPd_1 } & 0.304 & 0.334 & 0.363 & -1.631 & 0.071 & -0.845 \\
\hline & $(0.134)^{\star \star}$ & $(0.189)^{\star}$ & $(0.192)^{\star}$ & $(0.623)^{\star \star}$ & $(0.375)$ & $(0.691)$ \\
\hline \multirow[t]{2}{*}{ growtho } & -0.021 & 0.115 & 0.117 & 0.008 & 0.022 & -0.261 \\
\hline & $(0.021)$ & $(0.067)^{\star}$ & $(0.067)^{\star}$ & $(0.054)$ & $(0.057)$ & $(0.134)^{\star}$ \\
\hline
\end{tabular}




\begin{tabular}{|c|c|c|c|c|c|c|}
\hline growthd & 0.101 & 0.061 & 0.063 & 0.049 & -0.173 & -0.504 \\
\hline & $(0.077)$ & $(0.079)$ & $(0.080)$ & $(0.108)$ & $(0.132)$ & $(0.242)^{\star \star}$ \\
\hline \multirow[t]{2}{*}{ Relative GDP_1 } & 0.163 & 0.106 & 0.107 & -0.481 & -0.011 & -0.463 \\
\hline & $(0.082)^{\star \star}$ & $(0.101)$ & $(0.101)$ & $(0.170)^{\star \star \star}$ & $(0.089)$ & $(0.228)^{\star}$ \\
\hline \multirow[t]{2}{*}{ Polityo } & -0.003 & 0.004 & 0.004 & 0.008 & 0.021 & -0.030 \\
\hline & $(0.003)$ & $(0.009)$ & $(0.009)$ & $(0.013)$ & $(0.017)$ & $(0.016)^{\star}$ \\
\hline \multirow[t]{2}{*}{ Polityd } & 0.042 & 0.016 & 0.019 & -0.004 & 0.042 & 0.051 \\
\hline & $(0.012)^{\star \star \star}$ & $(0.017)$ & $(0.017)$ & $(0.030)$ & $(0.033)$ & $(0.029)^{\star}$ \\
\hline \multirow[t]{2}{*}{ col.InGDPo_1 } & 0.238 & & & & & \\
\hline & $(0.104)^{\star \star}$ & & & & & \\
\hline \multirow[t]{2}{*}{$\mathrm{nb} \cdot \operatorname{lnGDPd} \_1$} & -0.416 & & & 1.751 & 0.640 & 1.608 \\
\hline & $(0.160)^{\star \star}$ & & & $(0.773)^{\star \star}$ & $(0.720)$ & $(0.876)^{\star}$ \\
\hline \multirow[t]{2}{*}{ nb.relGDP_1 } & -0.309 & -0.243 & -0.236 & 0.386 & 0.366 & 0.899 \\
\hline & $(0.100)^{\star \star \star}$ & $(0.122)^{\star \star}$ & $(0.123)^{\star}$ & $(0.178)^{\star \star}$ & $(0.220)$ & $(0.285)^{\star \star \star}$ \\
\hline \multirow[t]{2}{*}{ dist.InGDP_1 } & 0.048 & 0.031 & 0.030 & & & 0.072 \\
\hline & $(0.010)^{\star \star \star}$ & $(0.011)^{\star \star \star}$ & $(0.011)^{\star \star \star}$ & & & $(0.023)^{\star \star \star}$ \\
\hline \multirow[t]{2}{*}{ dist._InGDPd_1 } & 0.053 & 0.057 & 0.057 & & & -0.139 \\
\hline & $(0.012)^{\star \star \star}$ & $(0.018)^{\star \star \star}$ & $(0.018)^{\star \star \star}$ & & & $(0.064)^{\star \star}$ \\
\hline \multirow[t]{2}{*}{ Indiaspora·Polityo } & 0.002 & & & & & \\
\hline & $(0.001)^{\star \star}$ & & & & & \\
\hline \multirow[t]{2}{*}{ Indiaspora·Polityd } & -0.006 & -0.005 & -0.005 & & & \\
\hline & $(0.002)^{\star \star \star}$ & $(0.002)^{\star \star}$ & $(0.002)^{\star \star}$ & & & \\
\hline \multirow[t]{2}{*}{ Indiaspora $\cdot \mathrm{kmdist}$} & -0.011 & -0.016 & -0.016 & & & \\
\hline & $(0.002)^{\star \star \star}$ & $(0.005)^{\star \star \star}$ & $(0.005)^{\star \star \star}$ & & & \\
\hline \multirow[t]{2}{*}{ Civil war } & 0.099 & 0.155 & 0.155 & -0.091 & 1.758 & 1.882 \\
\hline & $(0.046)^{\star \star}$ & $(0.075)^{\star \star}$ & $(0.075)^{\star \star}$ & $(0.110)$ & $(0.253)^{\star \star \star}$ & $(0.266)^{\star \star \star}$ \\
\hline \multirow[t]{2}{*}{ Intern. war } & 0.348 & 0.272 & 0.275 & 0.126 & 0.043 & 0.353 \\
\hline & $(0.088)^{\star \star \star}$ & $(0.163)^{\star}$ & $(0.163)^{\star}$ & $(0.229)$ & $(0.310)$ & $(0.311)$ \\
\hline \multirow[t]{2}{*}{ nb.growtho } & & 0.466 & 0.462 & 0.387 & -0.566 & \\
\hline & & $(0.268)^{\star}$ & $(0.264)^{\star}$ & $(0.136)^{\star \star \star}$ & $(0.496)$ & \\
\hline \multirow[t]{2}{*}{ dist.growtho } & & -0.022 & -0.022 & & & 0.042 \\
\hline & & $(0.008)^{\star \star \star}$ & $(0.008)^{\star \star \star}$ & & & $(0.011)^{\star \star \star}$ \\
\hline Fragile dummy & & & 0.195 & & & \\
\hline (destination) & & & $(0.223)$ & & & \\
\hline \multirow[t]{2}{*}{ nb·InGDPo_1 } & & & & -1.259 & -1.878 & -1.417 \\
\hline & & & & $(0.342)^{\star \star \star}$ & $(0.854)^{\star \star}$ & $(0.809)^{\star}$ \\
\hline \multirow[t]{2}{*}{ Indiaspora.nb } & & & & -0.495 & & \\
\hline & & & & $(0.148)^{\star \star \star}$ & & \\
\hline \multirow[t]{2}{*}{ Inrefugees_1 } & & & & & 0.598 & 2.628 \\
\hline & & & & & $(0.040)^{\star \star \star}$ & $(0.643)^{\star \star \star}$ \\
\hline \multirow[t]{2}{*}{ Inrefugees._nb } & & & & & -0.173 & -0.403 \\
\hline & & & & & $(0.070)^{\star \star}$ & $(0.096)^{\star \star \star}$ \\
\hline \multirow[t]{2}{*}{ dist.growthd } & & & & & & 0.064 \\
\hline & & & & & & $(0.021)^{\star \star \star}$ \\
\hline \multirow[t]{2}{*}{ dist.relGDP_1 } & & & & & & -0.038 \\
\hline & & & & & & $(0.013)^{\star \star \star}$ \\
\hline Inrefugees·InGDPd_1 & & & & & & -0.220 \\
\hline
\end{tabular}




\begin{tabular}{|c|c|c|c|c|c|c|}
\hline & & & & & & $(0.075)^{\star \star \star}$ \\
\hline \multirow[t]{2}{*}{ Inrefugees·relGDP_1 } & & & & & & -0.080 \\
\hline & & & & & & $(0.023)^{\star \star \star}$ \\
\hline \multirow[t]{2}{*}{ Lnrefugees_1·kmdist } & & & & & & -0.068 \\
\hline & & & & & & $(0.017)^{\star \star \star}$ \\
\hline \multirow[t]{2}{*}{ 1970s } & 0.016 & -0.034 & -0.045 & -0.099 & -0.712 & -1.087 \\
\hline & $(0.324)$ & $(0.387)$ & $(0.389)$ & $(0.840)$ & $(0.428)$ & $(0.432)^{\star \star}$ \\
\hline \multirow[t]{2}{*}{ 1980s } & 0.053 & 0.149 & 0.130 & 0.695 & -0.643 & -1.065 \\
\hline & $(0.348)$ & $(0.420)$ & $(0.422)$ & $(0.919)$ & $(0.346)^{\star}$ & $(0.358)^{\star \star \star}$ \\
\hline \multirow[t]{2}{*}{ 1990s } & -0.491 & -0.218 & -0.251 & 0.008 & -0.086 & -0.210 \\
\hline & $(0.342)$ & $(0.383)$ & $(0.386)$ & $(0.967)$ & $(0.317)$ & $(0.311)$ \\
\hline \multirow[t]{2}{*}{ EAP_o } & 0.249 & & & & & 2.525 \\
\hline & $(0.091)^{\star \star \star}$ & & & & & $(0.427)^{\star \star \star}$ \\
\hline \multirow[t]{2}{*}{ MNA_O } & 0.150 & & & & & \\
\hline & $(0.090)^{\star}$ & & & & & \\
\hline \multirow[t]{2}{*}{ SSA_O } & -0.197 & & & 0.451 & 0.627 & 1.181 \\
\hline & $(0.117)^{\star}$ & & & $(0.243)^{\star}$ & $(0.222)^{\star \star \star}$ & $(0.250)^{\star \star \star}$ \\
\hline \multirow[t]{2}{*}{ NAM_d } & 0.873 & 1.327 & 1.298 & & & \\
\hline & $(0.307)^{\star \star \star}$ & $(0.422)^{\star \star \star}$ & $(0.427)^{\star \star \star}$ & & & \\
\hline \multirow[t]{2}{*}{ SAR_d } & -0.742 & & & & & -0.964 \\
\hline & $(0.310)^{\star \star}$ & & & & & $(0.236)^{\star \star \star}$ \\
\hline \multirow[t]{2}{*}{ SAR_o } & & 0.487 & 0.488 & & & \\
\hline & & $(0.148)^{\star \star \star}$ & $(0.149)^{\star \star \star}$ & & & \\
\hline \multirow[t]{2}{*}{ LAC_d } & & -0.686 & -0.650 & -0.946 & -0.592 & \\
\hline & & $(0.343)^{\star \star}$ & $(0.349)^{\star}$ & $(0.247)^{\star \star \star}$ & $(0.158)^{\star \star \star}$ & \\
\hline \multirow[t]{2}{*}{ MNA_d } & & -0.985 & -0.941 & & & -0.775 \\
\hline & & $(0.402)^{\star \star}$ & $(0.405)^{\star \star}$ & & & $(0.406)^{\star}$ \\
\hline \multirow[t]{2}{*}{ LAC_0 } & & & & & & 1.780 \\
\hline & & & & & & $(0.317)^{\star \star \star}$ \\
\hline \multirow[t]{2}{*}{ Constant } & -10.466 & -11.345 & -11.854 & 7.853 & -4.683 & 6.361 \\
\hline & $(1.842)^{\star \star \star}$ & $(2.512)^{\star \star \star}$ & $(2.523)^{\star \star \star}$ & $(4.596)^{\star}$ & $(4.036)$ & $(6.147)$ \\
\hline Observations & 32348 & 10344 & 10344 & 2344 & 3324 & 3324 \\
\hline R-squared & 0.76 & 0.76 & 0.76 & 0.87 & 0.54 & 0.57 \\
\hline
\end{tabular}

Note: Robust standard errors in parentheses, * significant at $10 \%$; ** significant at $5 \%$; ** significant at $1 \%$. ' 0 ' denotes variables for the country of origin and ' $d$ ' variables for the countries of destination. Diaspora is the stock of migrants as measured ten years ago. Incomes (GDP and relative GDP) and population are also measured ten years ago. Growth, war and polity are measured as averages in the preceding decade. LAC: Latin America and the Caribbean, MNA: Middle East and North Africa, NAM: Northern America, SSA: Sub-Saharan Africa, EAP: East Asia \& Pacific, SAR: South Asia Region.

\section{Column 1: migration from poor and middle income countries}

Column 1 presents a migration model of migration from poor and middle income countries to the rest of the world. The results are similar to Collier and Hoeffler (2011) and show that migration is associated with a number of push and pull factors:

- People leave countries with low incomes and are attracted to countries with higher incomes. However, the pull of higher incomes is greater than the push of low incomes. If 
origin country incomes increase by $1 \%$, the stock of migrants decreases by $0.2 \%$, but if destination country incomes increase by $1 \%$, the stock of migrants increases by $0.3 \%$. Migration also depends on comparable incomes in the destination countries. Relative income is captured as the ratio between comparable countries of destination and the income of the chosen destination. For example the comparable income for migration to a neighbouring country is the income of other neighbouring countries. "ii This shows that migrants prefer to emigrate to countries with comparably higher incomes. On the other hand, economic opportunity (measured as the growth rates in the country of origin and destination) does not appear to be significant.

- Political factors are less strong. Autocracy does not appear to push people out; this is perhaps because severe autocracies manage to control their borders more tightly and make emigration more difficult. Thus, even if people want to leave autocracies they are less able to do so. There is a slight pull factor from democratic regimes. If there is a one point improvement in the polity score, immigration increases by $4 \%$. A one point increase would for example correspond to the difference between Estonia (9) and Sweden (10).iii

- Extreme political events - like international and civil wars in the previous decade - do result in more migrants. International wars increase migration by about $350 \%$. However, international wars are very rare events; more common events are civil wars. A civil war increases migration by about $10 \%$.

- Geography is important, too. Neighbouring countries receive more migrants; the further away the destination country the less migration we observe. However, there are a number of interaction effects. For example, the obstacle of distance is less severe if the incomes in the destination as well as origin country are higher. The latter suggests that migration is an investment. Incomes in origin countries have to be relatively high to make the costly choice of emigration to a far away country. The results suggest that migrants from poor countries are more likely to go to neighbouring countries, whereas migrants from middle income countries are more likely to go to a richer country, even if it is a long distance away.

- Former colonial relationships do not in themselves determine migration, but migrants from relatively well-off former colonies are more likely to emigrate to the former colonial power.

- The most important determinant of migration appears to be the stock of existing migrants, or diaspora. The larger the existing diaspora the greater the subsequent migration flow (Docquier and Rapoport, 2012). The results here suggest that a $1 \%$ increase in the diaspora increases migration by $0.8 \%$. $^{\text {iv }}$

In summary, the results in column 1 suggest that migrants from poor and middle income countries have strong income pull and push factors, political determinants are less important, a diaspora has strong accumulation effects over time, most migrants settle in neighbouring countries and large distances make migration less likely, although this can be overcome by better off migrants. The overall explanatory power of the model is high, about three-quarters of the variation in the migration data are explained $\left(R^{2}=0.76\right)$.

\section{Columns 2 and 3: migration from fragile states}

Column 2 presents the resuls of a similar migration model for migrants from fragile states. The economic factors that determine migration from poor and middle income countries also seem to 
explain migration from fragile states. One difference to the previous model is that there is no evidence that political factors determine migration from fragile states. Another difference is that migration to neighbouring countries is a less popular choice. The model in the third column includes a dummy for destination countries that are fragile. This dummy is not statistically significant, indicating that the model explains migration to fragile as well as non-fragile countries.

\section{Column 4: migration from one fragile state to another}

This is the core model for this analysis. A number of explanatory variables have to be dropped; for example, there are no colonial relationships (i.e. no former colonial powers are fragile states) and since there are no fragile states in North America the region has been excluded as a destination.

- The diaspora is a significant pull factor, and the size of the effect is of the same magnitude as in the previous models.

- Whether or not a fragile state neighbours another fragile state seems to make little difference to the pattern or migration (i.e. the neighbourhood dummy is insignificant). The income variables show that higher than average incomes in origin countries result in more migration, while lower than average incomes in destination countries attract migrants. These results appear to be counter intuitive. However, the inter-relationship between incomes and neighbourhood is important in this model. About three-quarters of migrants from fragile states go to a neighbouring fragile country. So although the neighbour dummy is insignificant on its own, the interaction of this dummy with the income of the destination country is significant: migrants only go to a neighbouring country if the income there is higher. For this type of migration (to neighbours), low incomes in origin countries as well as high incomes (absolute and relative to other destinations) in destination countries increase migration. As in the previous models the pull factor of higher income is stronger than the push from low income.

- There is no effect of autocracy or democracy in the origin or destination country and neither civil war nor international war generate more migrants.

Although the explanatory power of the model is high $\left(\mathrm{R}^{2}=0.87\right)$ the model can neither fully explain the relatively high outmigration from Sub-Saharan African countries nor popularity of Latin America and the Carribean countries of destination.

To summarise, the migration from fragile state to fragile state seems to be mainly driven by economic considerations and not by political factors. It appears that migrants do not just jump out of the frying pan into the fire. When they migrate they choose neighbouring countries with a higher income than their own.

\section{Column 5: refugees from fragile state to fragile state (applying a migration model)}

The next model tests the same model as column 4, but this time for refugees. The aim is to find out if the model of "voluntary" migration is able to explain any of the "forced" migration? There are some similarities with the migration models:

- The presence of refugees in the destination country is a strong pull factor for new refugees (the coefficient on the resident stock of refugees is positive and significant).

- Refugees choose neighbouring countries. 
- Refugees flee from civil war.

However, the overall explanatory power of the analysis is not as high $\left(R^{2}=0.54\right)$, so rather than trying to use a migration model to explain refugee flows, I have developed a dedicated refugee model (column 6).

\section{Column 6: refugees from fragile state to fragile state (applying a refugee-only model)}

As before the model has been fitted to the data rather than testing a particular model developed by theory. This shows that:

- Existing refugees in a destination country are very important as a pull factor for fresh refugees from that fragile state. An increase of $1 \%$ of the previous numbers results in a $2.6 \%$ increase in new refugees.

- Almost all refugees go to neighbouring countries (98\%).

- It seems that refugees choose neighbouring countries with higher absolute and relative income (when compared to other neighbours). Countries with low incomes have more refugees than higher income countries of origin and lower income countries of destination, and neighbouring countries with higher incomes attract more refugees than neighbouring countries with lower incomes.

- Refugees can overcome the obstacle of distance if income in their country of origin is higher and if the economic opportunities (growth) are higher at the country of destination. However, the presence of existing refugee populations somewhat weakens the effect of these economic considerations (see next point).

- Refugees are attracted to these countries because the refugees already installed are likely to be able to help them.

- Political variables are important. Civil wars in the country of origin in the previous decade increase the stock of refugees by about $190 \%$. Countries with higher democracy scores generate fewer migrants while more democratic regimes attract them. The pull of democracy is slightly higher than the push of autocracy.

The overall explanatory power of the regression is a little higher than the previous model: $R^{2}$ is now 0.57 .

Annex B presents alternative ways of clustering/correcting the standard errors. The focus is on the models presented in Table 5.1, columns 1, 4 and 6. The analysis in the annex demonstrates that the significance of the results is robust for each of the different methods of clustering by origin, destination or dyads. It uses a method suggested by Fafchamps and Gubert (2007), who developed a process for correcting the standard errors when using directed dyads. The standard errors are different according to the method chosen, but it is reassuring that the main results remain qualitatively similar. The estimations would benefit from further robustness checks. Possible endogeneity issues ${ }^{v}$ could be addressed by the use of General Methods of Moments (GMM) estimation (a standard dynamic panel estimation technique in panels with small " $t$ " and large " $\mathrm{n}$ ", where " $\mathrm{t}$ " stands for years and " $\mathrm{n}$ " for the number of countries). An exploration of country specific effects would provide further insights into the importance of income and political variables. 


\section{NOTES}

${ }^{\mathrm{i}}$ Migrants originate from 43 fragile states and can settle in 174 countries (including the other 42 fragile countries). In this present study, given that we have five observations per country pair we have potentially 37410 observations. The analysis of directed country pairs (or dyads) provides a number of econometric challenges. The errors are likely to be correlated. This might be the case because a number of countries also have reciprocal migration agreements. We want to account for possible correlation by either clustering the errors by country of origin, destination or dyad. We also use the method suggested by Fafchamps and Gubert (2007). For a more detailed discussion please refer to Collier and Hoeffler (2011).

ii If the migration destination is a rich country, the comparable income is the average income of the other rich countries. If the destination is neither a neighbour nor a rich country, the comparable income is the average income of all poor and middle income countries that do not border the country of origin.

iii 2010 values.

iv To see whether this coefficient is indeed smaller than one, I tested it and found the difference to be significant.

${ }^{\vee}$ For example, low/high income could be the result of migration rather than a cause; these endogenous issues are currently ignored. 


\section{Policy responses to date}

The Office of the United Nations High Commissioner for Refugees (UNHCR) is mandated to provide, on a non-political and humanitarian basis, international protection to refugees and to seek permanent solutions for them. The original UNHCR mandate was set out in 1950 and has been broadened by a number of UN General Assembly resolutions. In 2010 the UNHCR assisted 5.5 million refugees, 15.5 million internallydisplaced persons (IDPs) as well as asylum seekers, returnees and stateless persons. ${ }^{i}$

In contrast, although migration is highly restricted through national laws and regulations, there is no international regime for co-operation on and governance of international migration (for a discussion see Castles and Miller, 2009). The only international treaty is the United Nations International Convention on the Protection of the Rights of All Migrant Workers and Members of Their Families. As the title suggests this UN convention aims to protect migrant workers and members of their families and it emphasises the connection between migration and human rights. Although signed in 1990 it took 13 years to reach the threshold of 20 ratifying states to enter into force. In 2012 only 40 out of 192 UN members had ratified the convention and these countries are mainly emigration, not immigration, countries.

\section{NOTES}

\footnotetext{
${ }^{i}$ For more information see www.unhcr.org. For historical reasons the majority of Palestinian refugees do not fall under the UNHCR mandate. About 4.8 million registered Palestinian refugees are looked after in some 60 camps in the Middle East by United Nations Relief and Works Agency for Palestine Refugees in the Near East (UNRWA).
} 


\section{Entry points: looking at development in a new light}

As this paper is (to the author's best knowledge) the first large study of migration from and to fragile states, it is premature to provide specific policy recommendations. However, the patterns that are emerging point to some general areas in which the OECD could begin to increase its understanding of development and migration.

The research suggests that like other migration flows, the diaspora (or existing migrants) is an important pull factor for new migrants from fragile countries. It also suggests that increasing the income levels in fragile states is likely to increase migration to OECD countries and decrease migration to neighbouring fragile states. It also suggests that democratisation in fragile states is unlikely to reduce emigration. Development assistance that leads to higher incomes could therefore increase migration to the OECD, and this should be taken into consideration in the OECD's development assistance strategy.

The factors explaining the movements of refugees are similar. Refugees leave countries of low income and go to countries with higher incomes. They also tend to settle where there are already other refugees. However, unlike for general migration, political factors are a bigger influence on the movements of refugees. Weak democracy can push them from a country and destination countries with stronger democracy attract them. Civil wars are also an important determinant of refugee movements.

While there is a well co-ordinated international policy response to refugee crises, there is currently no international co-ordination of migration. Unlike other important development issues like aid, trade and debt, migration is currently not widely understood as a development issue. To address the issues of aid, trade and debt international institutions and rules have been generated, but not for migration.

Pritchett (2006) makes a strong case for migration as an important development issue. He argues that unskilled labour is the primary asset of the poor. By restricting labour mobility we are closing off one route out of poverty. The gap in real wages between rich and poor countries is about 10 to 1 . However, our current understanding of "development" focuses exclusively on nation-states, not nationals. Development is only about the interests of nation states and nation states are primarily concerned with the incomes of people within their boundaries rather than with the wellbeing of their nationals, wherever they may live. This current concept of "development" would radically change if international agencies shifted from their emphasis on improving the wellbeing of individuals who live in Sudan, Haiti and Tajikistan to assisting Sudanese, Haitians and Tajiks irrespective of where they live (Pritchett, 2006).

However, public opinion in most (rich) countries is anti-migration, even though there is evidence that migration is economically beneficial for rich countries (for example see World Bank, 2006). ${ }^{i}$ Concerns about jobs, security, cultural differences and social peace dominate the debate. It is unlikely that the debate in favour of lowering immigration controls can be won using economic arguments. However, the political acceptance of immigration may improve due to the change in demographics. The average fertility rate in the OECD is about 1.7 children per woman. For the European Union countries the fertility rate is even lower, at 1.6. Outside Europe Japan has very low rates (1.4) and Korea has the lowest fertility rate (1.2). A fertility rate of 2.1 keeps the population stable in rich countries, but only four OECD countries have such high rates: Israel, Iceland, New Zealand and Turkey. As a result, the dependency ratio in many OECD countries will increase over time, which exerts pressure on pensions and care for the elderly. A possible solution is an increase of immigration, which would lower the dependency ratio.

If policy makers wanted to increase labour mobility and lower the dependency ratio, how could migration rules be changed in the face of low political acceptance? Pritchett (2006) and Castles and Miller (2009) suggest that there is considerable evidence that planned and controlled entries result in acceptable social conditions for migrants as well as social peace between migrants and locals. Immigration quota systems 
are generally decided through regular political processes which permit public discussion. Participation in an open immigration rule decision process appears to increase the acceptability of immigration programmes. However, the countries that currently use quota systems typically try to attract high skill workers. To support development in fragile states as well, this would have to be changed to accommodate applications from low skilled workers. Unskilled migration may also be more acceptable if (1) there is a temporary status for immigrants; and (2) immigration is rationed to specific jobs or perhaps regions. Since international agreements on labour mobility are unlikely to be reached in the near future, a more realistic aim may be to encourage bilateral agreements.

\section{NOTE}

' For a recent survey see Card et al. 2009. 


\section{Conclusions and areas for future research}

The main research question asked in this paper was whether migrants leaving fragile states choose their destination country or whether they often have no other option than to settle in another fragile state? The conclusion from the statistical analysis is that there are rational -usually economic - reasons why people migrate from one fragile state to another, it is not simply the case that migrants jump from "the frying pan into the fire".

To take forward the development implications of this, outlined in the previous section, further research and policy advocacy could usefully explore the following issues:

1) The costs and benefits of migration from and to fragile states, following the calculation presented in World Bank (2006), and specifically of how migration affects fragile states. Other than the studies mentioned in Section 3.2, little research has been done on this subject. For example, the analysis presented here suggests that men are more likely to emigrate from fragile states, as are wealthier (and most likely) more educated individuals. These migrant characteristics may have a differential impact on the economy and the institutions of the country they leave behind.

2) How the change in the status of a fragile state affects migration. This would involve a re-estimation of the empirical model taking into consideration that the status of fragility can change over time. Furthermore, the different models (estimated on different sample sizes) cannot be compared directly. In order to compare fragile and non-fragile countries, a dummy variable for fragile countries should be included in the global model and interacted with the variables of interest, such as income and democracy.

3) How the existing UN convention on migration can be strengthened.

4) Which origin and destination countries would benefit from bilateral agreements governing quotas of immigrants, lengths of stay and rights for migrants, and how such agreements should be designed.

\section{NOTES}

\footnotetext{
i The OECD does not provide a list of fragile and conflict-affected states over time. A dynamic approach would categorise countries so that we can allow for temporal fragility and conflict. There are a number of data sets which allow such a categorisation over time. The World Bank's Country Policy and Institutional Assessment (CPIA) indicator was used in Chauvet et al. (2012) to identify "failing states". One issue with the use of the CPIA is that historical data are confidential and I would not be able to pass on the data for other researchers to replicate my work. Another issue is that the decision to make the CPIA index public has probably caused a structural break in the data series. There are good reasons to assume that the "public" CPIA takes higher values than the previous "confidential" CPIA. An alternative would be to use the open data source generated by Goldstone et al. (2010) to classify "politically unstable" countries and countries involved in armed conflict.
} 


\section{Bibliography}

Batista, C. and P. Vicente (2012), "Do Migrants Improve Governance at Home? Evidence from a Voting Experiment", World Bank Economic Review, forthcoming.

Card, D., C. Dustmann and I. Preston (2009), "Immigration, Wages, and Compositional Amenities", CReAM Discussion Paper No 29/09, Centre for Research and Analysis of Migration (CReAM), Department of Economics, University College London.

Castles, S. and M.J. Miller (2009), The Age of Migration: International Population Movements in the Modern World, $4^{\text {th }}$ edition, Palgrave Macmillan, Basingstoke.

Chauvet L., P. Collier and A. Hoeffler (2010), "Paradise Lost: The Cost of State Failure in the Pacific. Understanding Small-Island Developing States: Fragility and External Shocks", in Santos-Paulino, A., M. McGillivray and W. Naudé (eds.), Special Issue of the Journal of Development Studies 46(5):961-980.

Chauvet L., P. Collier and A. Hoeffler (2011), "The Cost of State Failure and the Limits to Sovereignty", in: Naudé, W.A., Santos-Paulino, A. and McGillivray, M. (eds). Fragile States: Causes, Costs, and Responses, Oxford University Press, Oxford.

Chauvet L., P. Collier and A. Hoeffler (2012), "The Cost of State Failure and the Limits to Sovereignty", in: Naudé, W.A., Santos-Paulino, A. and McGillivray, M. (eds). Fragile States: Causes, Costs, and Responses, Oxford University Press, Oxford.

Collier, P. and A. Hoeffler (2011), Quantitative Analysis of Determinants of International Migration, analysis commissioned as part of the UK Government's Foresight Project on Migration and Global Environmental Change, Government Office for Science, London, available at www.bis.gov.uk/assets/bispartners/foresight/docs/migration/drivers/11-1180-dr10-quantativedeterminants-of-international-migration.pdf

Docquier, F. and Rapoport, H. (2009), "Documenting the Brain Drain of 'la Crème de la Crème': Three case studies on international migration at the upper tail of the education distribution", Journal of Economics and Statistics 229 (6): 679-705.

Docquier, F. and Rapoport, H. (2012), "Globalisation, Brain Drain, and Development", Journal of Economic Literature, forthcoming.

Docquier F., E. Lodigiani, H. Rapoport and M. Schiff (2009), Brain Drain and Home Country Institutions, Unpublished mimeo.

ESDS International (2011), World Development Indicators, ESDS International, University of Manchester, Manchester.

Fafchamps, M. and Gubert, F. (2007), "The Formation of Risk Sharing Networks", Journal of Development Economics 83(2): 326-350.

Foresight (2011), Migration and Global Environmental Change. Final Project Report, The Government Office for Science, London, available at www.bis.gov.uk/foresight/our-work/projects/currentprojects/global-migration/reports-publications

Gleditsch, N.P., Wallensteen, P., Eriksson, M., Sollenberg, M. and H. Strand (2002), "Armed Conflict 1946-2001: A New Dataset", Journal of Peace Research 39(5): 615-637.

Goldin, I., G. Cameron and M. Balarajan (2011), Exceptional People: How Migration Shaped our World and Will Define our Future, Princeton University Press, Princeton NJ.

Goldstone, J., et al. (2010), "A Global Forecasting Model of Political Instability", American Journal of Political Science 54(1): 190-208. 
Hear van, N. (1998), New Diasporas, UCL Press, London.

Hoeffler, A. (2008), Dealing with the Consequences of Violent Conflicts in Africa, Background paper for the African Development Bank Report 2008, ADB, Abidjan, available at http://users.ox.ac.uk/ ball0144/consequences.pdf

OECD (Organisation for Economic Co-operation and Development) (2010), Annual Report on Resource Flows to Fragile States, OECD Development Assistance Committee (DAC) International Network on Conflict and Fragility (INCAF), OECD, Paris.

OECD (2011), Supporting Statebuilding in Situations of Conflict and Fragility: Policy Guidance, DAC Guidelines and Reference Series, OECD Publishing.

Özden, Ç., Parsons, C. R., Schiff, M. and T.L. Walmsley (2011), "Where on Earth is Everybody? The Evolution of Global Bilateral Migration 1960-2000", World Bank Economic Review 25(1): 12-56.

Pritchett, L. (2006), Let Their People Come: Breaking the Gridlock on Global Labor Mobility, Center For Global Development, Washington DC.

Richmond, A. (1994), Global Apartheid, Oxford University Press, Oxford.

UNHCR (Office of the United Nations High Commissioner for Refugees) (2007), UNHCR Statistical Online Population Database: Sources, Methods and Data Considerations, UNHCR, New York, available at www.unhcr.org/statistics/STATISTICS/45c06c662.htm/\#refugees

UNHCR (2010), Convention and Protocol Relating to the Status of Refugees, UNHCR, New York, available at www.unhcr.org/3b66c2aa10.html

UNHCR (2012), UNHCR Statistical Online Population Database, UNHCR, New York, available at www.unhcr.org/pages/4a013eb06.html.

World Bank, The (2006), Global Economic Prospects: Economic Implications of Remittances and Migration 2006, The World Bank, Washington DC. 


\section{Annex A: Country definitions}

High income OECD: Australia, Austria, Belgium, Canada, Czech Republic, Denmark, Finland, France, Germany, Greece, Hungary, Iceland, Ireland, Italy, Japan, Korea, Rep., Luxembourg, Netherlands, New Zealand, Norway, Portugal, Slovak Republic, Spain, Sweden, Switzerland, United Kingdom, United States.

Other high income: Andorra, Antigua and Barbuda, Aruba, The Bahamas, Bahrain, Barbados, Bermuda, Brunei Darussalam, Cayman Islands, Channel Islands, Cyprus, Estonia, Faeroe Islands, French Polynesia, Greenland, Guam, Hong Kong, Isle of Man, Israel, Kuwait, Liechtenstein, Macao, Malta, New Caledonia, Northern Mariana Islands, Oman, Puerto Rico, Qatar, San Marino, Saudi Arabia, Singapore, Slovenia, South Africa, Trinidad and Tobago, United Arab Emirates, Virgin Islands (U.S.)

Middle income and poor: Albania, Algeria, American Samoa, Argentina, Armenia, Azerbaijan, Bangladesh, Belarus, Belize, Benin, Bhutan, Bolivia, Bosnia and Herzegovina, Botswana, Brazil, Bulgaria, Burkina Faso, Cambodia, Cape Verde, Chile, China, Colombia, Costa Rica, Croatia, Cuba, Dominica, Dominican Republic, Ecuador, Egypt, Arab Rep. ,El Salvador, Fiji, Gabon, Georgia, Ghana, Grenada, Guatemala, Guyana, Honduras, India, Indonesia, Iran, Jamaica, Jordan, Kazakhstan, Kyrgyz Republic, Lao PDR, Latvia, Lebanon, Lesotho, Libya, Lithuania, Macedonia, Madagascar, Malawi, Malaysia, Maldives, Mali, Marshall Islands, Mauritania, Mauritius, Mayotte, Mexico, Micronesia, Moldova, Mongolia, Morocco, Mozambique, Namibia, Nicaragua, Palau, Panama, Paraguay, Peru, Philippines, Poland, Romania, Russian Federation, Samoa, Senegal, Serbia, Seychelles, Sri Lanka, St. Kitts and Nevis, St. Lucia, St. Vincent and the Grenadines, Suriname, Swaziland, Syrian Arab Republic, Tanzania, Thailand, Tunisia, Turkey, Turkmenistan, Ukraine, Uruguay, Uzbekistan, Vanuatu, Venezuela, Vietnam, Zambia

Fragile states - list of countries as in OECD (2010)

Low-income countries (26 countries): Afghanistan, Burundi, Central African Republic, Chad, Democratic Republic of Congo, Comoros, Eritrea, Ethiopia, Gambia, Guinea, Guinea-Bissau, Haiti, Kenya, North Korea, Liberia, Myanmar, Nepal, Niger, Rwanda, Somalia, Sierra Leone, Tajikistan, Togo, Uganda, Republic of Yemen, Zimbabwe

Middle-income countries and economies (16 countres and economies): Angola, Cameroon, Republic of Congo, Côte d'Ivoire, Djibouti, Iraq, Kiribati, Nigeria, São Tomé and Principe, Solomon Islands, Sudan, Timor-Leste, Tonga, Pakistan, Papua New Guinea, West Bank and Gaza

High-income countries (1 country): Equatorial Guinea 


\section{Annex B: Alternative treatment of the standard errors}

Table B1. Migration from poor \& middle income countries to the world (Model 1, Table 5.1)

\begin{tabular}{|c|c|c|c|}
\hline & (1) & (2) & (3) \\
\hline & SE clustered by destination & SE clustered by origin & SE clustered by dyad \\
\hline \multirow[t]{2}{*}{ Indiaspora } & 0.844 & 0.844 & 0.844 \\
\hline & $(0.022)^{\star \star \star}$ & $(0.010)^{\star \star \star}$ & $(0.007)^{\star \star \star}$ \\
\hline \multirow[t]{2}{*}{ col } & -1.381 & -1.381 & -1.381 \\
\hline & $(0.837)$ & (1.003) & (0.927) \\
\hline \multirow[t]{2}{*}{$\mathrm{nb}$} & 4.437 & 4.437 & 4.437 \\
\hline & $(1.476)^{\star \star \star}$ & $(0.868)^{\star \star \star}$ & $(0.732)^{\star \star \star}$ \\
\hline \multirow[t]{2}{*}{ kmdist } & -0.968 & -0.968 & -0.968 \\
\hline & $(0.121)^{\star \star \star}$ & $(0.104)^{\star \star \star}$ & $(0.054)^{\star \star \star}$ \\
\hline \multirow{2}{*}{ Inpwtpopo_1 } & 0.284 & 0.284 & 0.284 \\
\hline & $(0.030)^{\star \star \star}$ & $(0.022)^{\star \star \star}$ & $(0.016)^{\star \star \star}$ \\
\hline \multirow[t]{2}{*}{ Inpwtpopd_1 } & 0.391 & 0.391 & 0.391 \\
\hline & $(0.056)^{\star \star \star}$ & $(0.018)^{\star \star \star}$ & $(0.013)^{\star \star \star}$ \\
\hline \multirow[t]{2}{*}{ Inrgdpcho_1 } & -0.229 & -0.229 & -0.229 \\
\hline & $(0.076)^{\star \star \star}$ & $(0.075)^{\star \star \star}$ & $(0.047)^{\star \star \star}$ \\
\hline \multirow[t]{2}{*}{ Inrgdpchd_1 } & 0.304 & 0.304 & 0.304 \\
\hline & $(0.134)^{\star \star}$ & $(0.056)^{\star \star \star}$ & $(0.038)^{\star \star \star}$ \\
\hline \multirow[t]{2}{*}{ xwgyo } & -0.021 & -0.021 & -0.021 \\
\hline & $(0.021)$ & $(0.027)$ & $(0.024)$ \\
\hline \multirow[t]{2}{*}{ xwgyd } & 0.101 & 0.101 & 0.101 \\
\hline & $(0.077)$ & $(0.019)^{\star \star \star}$ & $(0.021)^{\star \star \star}$ \\
\hline \multirow[t]{2}{*}{ relrgdpch_1 } & 0.163 & 0.163 & 0.163 \\
\hline & $(0.082)^{\star \star}$ & $(0.015)^{\star \star \star}$ & $(0.018)^{\star \star \star}$ \\
\hline \multirow[t]{2}{*}{ polityo } & -0.003 & -0.003 & -0.003 \\
\hline & $(0.003)$ & $(0.005)$ & $(0.004)$ \\
\hline \multirow[t]{2}{*}{ polityd } & 0.042 & 0.042 & 0.042 \\
\hline & $(0.012)^{\star \star \star}$ & $(0.003)^{\star \star \star}$ & $(0.003)^{\star \star \star}$ \\
\hline \multirow[t]{2}{*}{ col_Inrgdpcho_1 } & 0.238 & 0.238 & 0.238 \\
\hline & $(0.104)^{\star \star}$ & $(0.122)^{\star}$ & $(0.116)^{\star \star}$ \\
\hline \multirow[t]{2}{*}{ nb_Inrgdpchd_1 } & -0.416 & -0.416 & -0.416 \\
\hline & $(0.160)^{\star \star}$ & $(0.096)^{\star \star \star}$ & $(0.083)^{\star \star \star}$ \\
\hline \multirow[t]{2}{*}{ nb_relrgdpch_1 } & -0.309 & -0.309 & -0.309 \\
\hline & $(0.100)^{\star \star \star}$ & $(0.058)^{\star \star \star}$ & $(0.047)^{\star \star \star}$ \\
\hline \multirow[t]{2}{*}{ dist_Inrgdpcho_1 } & 0.048 & 0.048 & 0.048 \\
\hline & $(0.010)^{\star \star \star}$ & $(0.010)^{\star \star \star}$ & $(0.005)^{\star \star \star}$ \\
\hline
\end{tabular}




\begin{tabular}{|c|c|c|c|}
\hline \multirow[t]{2}{*}{ dist_Inrgdpchd_1 } & 0.053 & 0.053 & 0.053 \\
\hline & $(0.012)^{\star \star \star}$ & $(0.007)^{\star \star \star}$ & $(0.004)^{\star \star \star}$ \\
\hline \multirow[t]{2}{*}{ Indias_polityo } & 0.002 & 0.002 & 0.002 \\
\hline & $(0.001)^{\star \star}$ & $(0.001)^{\star \star \star}$ & $(0.000)^{\star \star \star}$ \\
\hline \multirow[t]{2}{*}{ Indias_polityd } & -0.006 & -0.006 & -0.006 \\
\hline & $(0.002)^{\star \star \star}$ & $(0.000)^{\star \star \star}$ & $(0.000)^{\star \star \star}$ \\
\hline \multirow[t]{2}{*}{ Indias_kmdist } & -0.011 & -0.011 & -0.011 \\
\hline & $(0.002)^{\star \star \star}$ & $(0.001)^{\star \star \star}$ & $(0.001)^{\star \star \star}$ \\
\hline \multirow[t]{2}{*}{ civwar1 } & 0.099 & 0.099 & 0.099 \\
\hline & $(0.046)^{\star \star}$ & $(0.070)$ & $(0.052)^{\star}$ \\
\hline \multirow[t]{2}{*}{ intwar1 } & 0.348 & 0.348 & 0.348 \\
\hline & $(0.088)^{\star \star \star}$ & $(0.103)^{\star \star \star}$ & $(0.080)^{\star \star \star}$ \\
\hline \multirow[t]{2}{*}{ eap_o } & 0.249 & 0.249 & 0.249 \\
\hline & $(0.091)^{\star \star \star}$ & $(0.112)^{\star \star}$ & $(0.069)^{\star \star \star}$ \\
\hline \multirow[t]{2}{*}{ mna_o } & 0.150 & 0.150 & 0.150 \\
\hline & $(0.090)^{\star}$ & $(0.101)$ & $(0.074)^{\star \star}$ \\
\hline \multirow[t]{2}{*}{ ssa_o } & -0.197 & -0.197 & -0.197 \\
\hline & $(0.117)^{\star}$ & $(0.083)^{\star \star}$ & $(0.058)^{\star \star \star}$ \\
\hline \multirow[t]{2}{*}{ nam_d } & 0.873 & 0.873 & 0.873 \\
\hline & $(0.307)^{\star \star \star}$ & $(0.093)^{\star \star \star}$ & $(0.080)^{\star \star \star}$ \\
\hline \multirow[t]{2}{*}{ sar_d } & -0.742 & -0.742 & -0.742 \\
\hline & $(0.310)^{\star \star}$ & $(0.135)^{\star \star \star}$ & $(0.087)^{\star \star \star}$ \\
\hline \multirow[t]{2}{*}{$\operatorname{dec} 70$} & 0.016 & 0.016 & 0.016 \\
\hline & $(0.324)$ & $(0.105)$ & $(0.089)$ \\
\hline \multirow[t]{2}{*}{ dec80 } & 0.053 & 0.053 & 0.053 \\
\hline & $(0.348)$ & $(0.130)$ & $(0.112)$ \\
\hline \multirow[t]{2}{*}{ dec90 } & -0.491 & -0.491 & -0.491 \\
\hline & $(0.342)$ & $(0.130)^{\star \star \star}$ & $(0.109)^{\star \star \star}$ \\
\hline \multirow[t]{2}{*}{ Constant } & -10.466 & -10.466 & -10.466 \\
\hline & $(1.842)^{\star \star \star}$ & $(0.924)^{\star \star \star}$ & $(0.676)^{\star \star \star}$ \\
\hline Observations & 32348 & 32348 & 32348 \\
\hline R-squared & 0.76 & 0.76 & 0.76 \\
\hline
\end{tabular}

Note: Robust standard errors in parentheses, * significant at 10\%; ** significant at 5\%; *** significant at $1 \%$. 
Table B2. Migration from fragile to fragile state (Model 4, Table 5.1)

\begin{tabular}{|c|c|c|c|c|}
\hline & (1) & (2) & (3) & (4) \\
\hline & $\begin{array}{l}\text { SE clustered by } \\
\text { destination }\end{array}$ & $\begin{array}{l}\text { SE clustered by } \\
\text { origin }\end{array}$ & $\begin{array}{l}\text { SE clustered by } \\
\text { dyad }\end{array}$ & $\begin{array}{l}\text { Fafchamps\&Gubert } \\
\text { corrected SE }\end{array}$ \\
\hline \multirow[t]{2}{*}{ Indiaspora } & 0.850 & 0.850 & 0.850 & 0.850 \\
\hline & $(0.027)^{\star \star \star}$ & $(0.020)^{\star \star \star}$ & $(0.015)^{\star \star \star}$ & $(0.030)^{\star \star \star}$ \\
\hline \multirow[t]{2}{*}{ neighbour } & -0.908 & -0.908 & -0.908 & -0.908 \\
\hline & $(5.943)$ & $(4.344)$ & $(4.470)$ & (7.069) \\
\hline \multirow[t]{2}{*}{ Km distance } & -0.111 & -0.111 & -0.111 & -0.111 \\
\hline & $(0.025)^{\star \star \star}$ & $(0.023)^{\star \star \star}$ & $(0.018)^{\star \star \star}$ & $(0.032)^{\star \star \star}$ \\
\hline \multirow[t]{2}{*}{ Inpopulationo_1 } & 0.109 & 0.109 & 0.109 & 0.109 \\
\hline & $(0.047)^{\star \star}$ & $(0.067)$ & $(0.049)^{\star \star}$ & $(0.057)^{\star}$ \\
\hline \multirow[t]{2}{*}{ Inpopulationd_1 } & 0.161 & 0.161 & 0.161 & 0.161 \\
\hline & $(0.088)^{\star}$ & $(0.032)^{\star \star \star}$ & $(0.038)^{\star \star \star}$ & $(0.082)^{\star \star}$ \\
\hline \multirow[t]{2}{*}{ InGDPo_1 } & 0.198 & 0.198 & 0.198 & 0.198 \\
\hline & $(0.077)^{\star \star}$ & $(0.137)$ & $(0.113)^{\star}$ & $(0.110)^{\star}$ \\
\hline \multirow[t]{2}{*}{ InGDPd_1 } & -1.631 & -1.631 & -1.631 & -1.631 \\
\hline & $(0.623)^{\star \star}$ & $(0.204)^{\star \star \star}$ & $(0.295)^{\star \star \star}$ & $(0.686)^{\star \star}$ \\
\hline \multirow[t]{2}{*}{ growtho } & 0.008 & 0.008 & 0.008 & 0.008 \\
\hline & $(0.054)$ & $(0.075)$ & $(0.069)$ & $(0.062)$ \\
\hline \multirow[t]{2}{*}{ growthd } & 0.049 & 0.049 & 0.049 & 0.049 \\
\hline & $(0.108)$ & $(0.071)$ & $(0.068)$ & $(0.119)$ \\
\hline \multirow[t]{2}{*}{ Relative GDP } & -0.481 & -0.481 & -0.481 & -0.481 \\
\hline & $(0.170)^{\star \star \star}$ & $(0.064)^{\star \star \star}$ & $(0.083)^{\star \star \star}$ & $(0.173)^{\star \star \star}$ \\
\hline \multirow[t]{2}{*}{ Polityo } & 0.008 & 0.008 & 0.008 & 0.008 \\
\hline & $(0.013)$ & $(0.017)$ & $(0.015)$ & $(0.013)$ \\
\hline \multirow[t]{2}{*}{ Polityd } & -0.004 & -0.004 & -0.004 & -0.004 \\
\hline & $(0.030)$ & $(0.013)$ & $(0.014)$ & $(0.033)$ \\
\hline \multirow[t]{2}{*}{ nb·InGDPo_1 } & -1.259 & -1.259 & -1.259 & -1.259 \\
\hline & $(0.342)^{\star \star \star}$ & $(0.419)^{\star \star \star}$ & $(0.438)^{\star \star \star}$ & $(0.437)^{\star \star \star}$ \\
\hline \multirow[t]{2}{*}{$\mathrm{nb} \cdot \operatorname{lnGDPd} \_1$} & 1.751 & 1.751 & 1.751 & 1.751 \\
\hline & $(0.773)^{\star \star}$ & $(0.432)^{\star \star \star}$ & $(0.480)^{\star \star \star}$ & $(0.670)^{\star \star \star}$ \\
\hline \multirow[t]{2}{*}{ nb.growtho } & 0.387 & 0.387 & 0.387 & 0.387 \\
\hline & $(0.136)^{\star \star \star}$ & $(0.090)^{\star \star \star}$ & $(0.118)^{\star \star \star}$ & $(0.120)^{\star \star \star}$ \\
\hline \multirow[t]{2}{*}{ nb.relGDP_1 } & 0.386 & 0.386 & 0.386 & 0.386 \\
\hline & $(0.178)^{\star \star}$ & $(0.117)^{\star \star \star}$ & $(0.157)^{\star \star}$ & $(0.180)^{\star \star}$ \\
\hline \multirow[t]{2}{*}{ Indiaspora.nb } & -0.495 & -0.495 & -0.495 & -0.495 \\
\hline & $(0.148)^{\star \star \star}$ & $(0.106)^{\star \star \star}$ & $(0.099)^{\star \star \star}$ & $(0.145)^{\star \star \star}$ \\
\hline \multirow[t]{2}{*}{ civilwar } & -0.091 & -0.091 & -0.091 & -0.091 \\
\hline & $(0.110)$ & $(0.134)$ & $(0.129)$ & $(0.151)$ \\
\hline
\end{tabular}




\begin{tabular}{|l|l|l|l|l|}
\hline Intern. war & 0.126 & 0.126 & 0.126 & 0.126 \\
\hline & $(0.229)$ & $(0.268)$ & $(0.265)$ & $(0.288)$ \\
\hline SSA_o & 0.451 & 0.451 & 0.451 & 0.451 \\
\hline & $(0.243)^{\star}$ & $(0.169)^{\star \star}$ & $(0.177)^{\star \star}$ & $(0.291)$ \\
\hline LAC_d & -0.946 & -0.946 & -0.946 & -0.946 \\
\hline & $(0.247)^{\star \star \star}$ & $(0.233)^{\star \star \star}$ & $(0.201)^{\star \star \star}$ & $(0.318)^{\star \star \star}$ \\
\hline 1970s & -0.099 & -0.099 & -0.099 & -0.099 \\
\hline & $(0.840)$ & $(0.341)$ & $(0.397)$ & $(0.686)$ \\
\hline $1980 s$ & 0.695 & 0.695 & 0.695 & 0.695 \\
\hline $1990 s$ & $(0.919)$ & $(0.454)$ & $(0.461)$ & $(0.807)$ \\
\hline & 0.008 & 0.008 & 0.008 & 0.008 \\
\hline Constant & $(0.967)$ & $(0.452)$ & $(0.485)$ & $(0.874)$ \\
\hline & 7.853 & 7.853 & 7.853 & 7.853 \\
\hline Observations & $(4.596)^{\star}$ & $(2.182)^{\star \star \star}$ & $(2.671)^{\star \star \star}$ & $(4.514)^{\star}$ \\
\hline R-squared & 2344 & 2344 & 2344 & 2344 \\
\hline
\end{tabular}

Note: Robust standard errors in parentheses, * significant at 10\%; ** significant at 5\%; ${ }^{\star \star \star}$ significant at $1 \%$.

Table B3. Refugees from fragile to fragile state (Model 4, Table 5.1)

\begin{tabular}{|c|c|c|c|c|}
\hline & (1) & (2) & (3) & (4) \\
\hline & $\begin{array}{l}\text { SE clustered by } \\
\text { destination }\end{array}$ & $\begin{array}{l}\text { SE clustered by } \\
\text { origin }\end{array}$ & $\begin{array}{l}\text { SE clustered by } \\
\text { dyad }\end{array}$ & $\begin{array}{l}\text { Fafchamps\&Gubert } \\
\text { corrected SE }\end{array}$ \\
\hline \multirow[t]{2}{*}{ Inrefugees_1 } & 2.628 & 2.628 & 2.628 & 2.628 \\
\hline & $(0.643)^{\star \star \star}$ & $(0.646)^{\star \star \star}$ & $(0.612)^{\star \star \star}$ & $(0.798)^{\star \star \star}$ \\
\hline \multirow[t]{2}{*}{$\mathrm{nb}$} & -0.878 & -0.878 & -0.878 & -0.878 \\
\hline & $(6.923)$ & $(10.738)$ & $(10.003)$ & $(10.354)$ \\
\hline \multirow[t]{2}{*}{ kmdist } & -0.506 & -0.506 & -0.506 & -0.506 \\
\hline & $(0.585)$ & $(0.429)$ & $(0.386)$ & $(0.702)$ \\
\hline \multirow[t]{2}{*}{ Inpwtpopo_1 } & 0.072 & 0.072 & 0.072 & 0.072 \\
\hline & $(0.044)$ & $(0.080)$ & $(0.050)$ & $(0.078)$ \\
\hline \multirow[t]{2}{*}{ Inpwtpopd_1 } & 0.304 & 0.304 & 0.304 & 0.304 \\
\hline & $(0.093)^{\star \star \star}$ & $(0.064)^{\star \star \star}$ & $(0.053)^{\star \star \star}$ & $(0.094)^{\star \star \star}$ \\
\hline \multirow[t]{2}{*}{ Inrgdpcho_1 } & -0.492 & -0.492 & -0.492 & -0.492 \\
\hline & $(0.151)^{\star \star \star}$ & $(0.343)$ & $(0.187)^{\star \star \star}$ & $(0.331)$ \\
\hline \multirow[t]{2}{*}{ Inrgdpchd_1 } & -0.845 & -0.845 & -0.845 & -0.845 \\
\hline & $(0.691)$ & $(0.724)$ & $(0.749)$ & $(1.021)$ \\
\hline \multirow[t]{2}{*}{ xwgyo } & -0.261 & -0.261 & -0.261 & -0.261 \\
\hline & $(0.134)^{\star}$ & $(0.183)$ & $(0.124)^{\star \star}$ & $(0.196)$ \\
\hline \multirow[t]{2}{*}{ xwgyd } & -0.504 & -0.504 & -0.504 & -0.504 \\
\hline & $(0.242)^{\star \star}$ & $(0.097)^{\star \star \star}$ & $(0.118)^{\star \star \star}$ & $(0.219)^{\star \star}$ \\
\hline relrgdpch_1 & -0.463 & -0.463 & -0.463 & -0.463 \\
\hline
\end{tabular}




\begin{tabular}{|c|c|c|c|c|}
\hline & $(0.228)^{\star}$ & $(0.227)^{\star \star}$ & $(0.219)^{\star \star}$ & $(0.301)$ \\
\hline \multirow[t]{2}{*}{ polityo } & -0.030 & -0.030 & -0.030 & -0.030 \\
\hline & $(0.016)^{\star}$ & $(0.033)$ & $(0.016)^{\star}$ & $(0.026)$ \\
\hline \multirow[t]{2}{*}{ polityd } & 0.051 & 0.051 & 0.051 & 0.051 \\
\hline & $(0.029)^{\star}$ & $(0.012)^{\star \star \star}$ & $(0.017)^{\star \star \star}$ & $(0.026)^{\star \star}$ \\
\hline \multirow[t]{2}{*}{ nb_Inrgdpcho_1 } & -1.417 & -1.417 & -1.417 & -1.417 \\
\hline & $(0.809)^{\star}$ & $(0.783)^{\star}$ & $(0.729)^{\star}$ & $(0.752)^{\star}$ \\
\hline \multirow[t]{2}{*}{ nb_Inrgdpchd_1 } & 1.608 & 1.608 & 1.608 & 1.608 \\
\hline & $(0.876)^{\star}$ & $(1.022)$ & $(1.116)$ & $(1.209)$ \\
\hline \multirow[t]{2}{*}{ nb_relrgdpch_1 } & 0.899 & 0.899 & 0.899 & 0.899 \\
\hline & $(0.285)^{\star \star \star}$ & $(0.387)^{\star \star}$ & $(0.318)^{\star \star \star}$ & $(0.522)^{\star}$ \\
\hline \multirow[t]{2}{*}{ dist_Inrgdpcho_1 } & 0.072 & 0.072 & 0.072 & 0.072 \\
\hline & $(0.023)^{\star \star \star}$ & $(0.041)^{\star}$ & $(0.022)^{\star \star \star}$ & $(0.037)^{\star}$ \\
\hline \multirow[t]{2}{*}{ dist_Inrgdpchd_1 } & -0.139 & -0.139 & -0.139 & -0.139 \\
\hline & $(0.064)^{\star \star}$ & $(0.046)^{\star \star \star}$ & $(0.040)^{\star \star \star}$ & $(0.080)^{\star}$ \\
\hline \multirow[t]{2}{*}{ dist_xwgyo } & 0.042 & 0.042 & 0.042 & 0.042 \\
\hline & $(0.011)^{\star \star \star}$ & $(0.014)^{\star \star \star}$ & $(0.010)^{\star \star \star}$ & $(0.016)^{\star \star \star}$ \\
\hline \multirow[t]{2}{*}{ dist_xwgyd } & 0.064 & 0.064 & 0.064 & 0.064 \\
\hline & $(0.021)^{\star \star \star}$ & $(0.011)^{\star \star \star}$ & $(0.010)^{\star \star \star}$ & $(0.021)^{\star \star \star}$ \\
\hline \multirow[t]{2}{*}{ dist_relrgdpch_1 } & -0.038 & -0.038 & -0.038 & -0.038 \\
\hline & $(0.013)^{\star \star \star}$ & $(0.013)^{\star \star \star}$ & $(0.011)^{\star \star \star}$ & $(0.016)^{\star \star}$ \\
\hline \multirow[t]{2}{*}{ Inref_rgdpchd_1 } & -0.220 & -0.220 & -0.220 & -0.220 \\
\hline & $(0.075)^{\star \star \star}$ & $(0.076)^{\star \star \star}$ & $(0.073)^{\star \star \star}$ & $(0.091)^{\star \star}$ \\
\hline \multirow[t]{2}{*}{ Inref_relrgdpch_1 } & -0.080 & -0.080 & -0.080 & -0.080 \\
\hline & $(0.023)^{\star \star \star}$ & $(0.022)^{\star \star \star}$ & $(0.021)^{\star \star \star}$ & $(0.031)^{\star \star}$ \\
\hline \multirow[t]{2}{*}{ Inref_nb } & -0.403 & -0.403 & -0.403 & -0.403 \\
\hline & $(0.096)^{\star \star \star}$ & $(0.085)^{\star \star \star}$ & $(0.081)^{\star \star \star}$ & $(0.104)^{\star \star \star}$ \\
\hline \multirow[t]{2}{*}{ Inref_kmdist } & -0.068 & -0.068 & -0.068 & -0.068 \\
\hline & $(0.017)^{\star \star \star}$ & $(0.020)^{\star \star \star}$ & $(0.016)^{\star \star \star}$ & $(0.020)^{\star \star \star}$ \\
\hline \multirow[t]{2}{*}{ civwar1 } & 1.882 & 1.882 & 1.882 & 1.882 \\
\hline & $(0.266)^{\star \star \star}$ & $(0.282)^{\star \star \star}$ & $(0.179)^{\star \star \star}$ & $(0.386)^{\star \star \star}$ \\
\hline \multirow[t]{2}{*}{ intwar1 } & 0.353 & 0.353 & 0.353 & 0.353 \\
\hline & $(0.311)$ & $(0.248)$ & $(0.325)$ & $(0.434)$ \\
\hline \multirow[t]{2}{*}{ eap_o } & 2.525 & 2.525 & 2.525 & 2.525 \\
\hline & $(0.427)^{\star \star \star}$ & $(0.406)^{\star \star \star}$ & $(0.255)^{\star \star \star}$ & $(0.524)^{\star \star \star}$ \\
\hline \multirow[t]{2}{*}{ lac_o } & 1.780 & 1.780 & 1.780 & 1.780 \\
\hline & $(0.317)^{\star \star \star}$ & $(0.291)^{\star \star \star}$ & $(0.223)^{\star \star \star}$ & $(0.362)^{\star \star \star}$ \\
\hline \multirow[t]{2}{*}{ ssa_o } & 1.181 & 1.181 & 1.181 & 1.181 \\
\hline & $(0.250)^{\star \star \star}$ & $(0.267)^{\star \star \star}$ & $(0.188)^{\star \star \star}$ & $(0.320)^{\star \star \star}$ \\
\hline \multirow[t]{2}{*}{ mna_d } & -0.775 & -0.775 & -0.775 & -0.775 \\
\hline & $(0.406)^{\star}$ & $(0.394)^{\star}$ & $(0.272)^{\star \star \star}$ & $(0.506)$ \\
\hline
\end{tabular}




\begin{tabular}{|l|l|l|l|l|}
\hline sar_d & -0.964 & -0.964 & -0.964 & -0.964 \\
\hline & $(0.236)^{\star \star \star}$ & $(0.303)^{\star \star \star}$ & $(0.233)^{\star \star \star}$ & $(0.298)^{\star \star \star}$ \\
\hline dec70 & -1.087 & -1.087 & -1.087 & -1.087 \\
\hline & $(0.432)^{\star \star}$ & $(0.480)^{\star \star}$ & $(0.269)^{\star \star \star}$ & $(0.441)^{\star \star}$ \\
\hline dec80 & -1.065 & -1.065 & -1.065 & -1.065 \\
\hline & $(0.358)^{\star \star \star}$ & $(0.424)^{\star \star}$ & $(0.240)^{\star \star \star}$ & $(0.459)^{\star \star}$ \\
\hline dec90 & -0.210 & -0.210 & -0.210 & -0.210 \\
\hline & $(0.311)$ & $(0.349)$ & $(0.188)$ & $(0.329)$ \\
\hline Constant & 6.361 & 6.361 & 6.361 & 6.361 \\
\hline & $(6.147)$ & $(7.391)$ & $(6.664)$ & $(8.747)$ \\
\hline Observations & 3324 & 3324 & 3324 & 3324 \\
\hline R-squared & 0.57 & 0.57 & 0.57 & \\
\hline
\end{tabular}

Note: Robust standard errors in parentheses, * significant at 10\%; ${ }^{\star *}$ significant at 5\%; ${ }^{* \star}$ significant at $1 \%$. 
